\title{
Para além do Pensamento Abissal: Das linhas globais a uma ecologia de saberes
}

Beyond Abyssal Thinking: From Global Lines to an Ecology of Knowledges

Par delà la Pensée Abyssale : des lignes globales à une écologie de savoirs

Boaventura de Sousa Santos

\section{CpenEdition}

\section{Journals}

Edição electrónica

URL: http://journals.openedition.org/rccs/753

DOI: $10.4000 /$ rccs.753

ISSN: 2182-7435

Editora

Centro de Estudos Sociais da Universidade de Coimbra

Edição impressa

Data de publição: 1 Outubro 2007

Paginação: 3-46

ISSN: 0254-1106

Refêrencia eletrónica

Boaventura de Sousa Santos, «Para além do Pensamento Abissal: Das linhas globais a uma ecologia de saberes », Revista Crítica de Ciências Sociais [Online], 78| 2007, colocado online no dia 01 outubro 2012, criado a 19 abril 2019. URL : http://journals.openedition.org/rccs/753 ; DOI : 10.4000/rccs.753 


\section{BOAVENTURA DE SOUSA SANTOS}

\section{Para além do Pensamento Abissal: Das linhas globais a uma ecologia de saberes*}

Na primeira parte do ensaio, argumenta-se que as linhas cartográficas "abissais" que demarcavam o Velho e o Novo Mundo na era colonial subsistem estruturalmente no pensamento moderno ocidental e permanecem constitutivas das relações políticas e culturais excludentes mantidas no sistema mundial contemporâneo. A injustiça social global estaria, portanto, estritamente associada à injustiça cognitiva global, de modo que a luta por uma justiça social global requer a construção de um pensamento "pós-abissal", cujos princípios são apresentados na segunda parte do ensaio como premissas programáticas de uma "ecologia de saberes".

O pensamento moderno ocidental é um pensamento abissal. ${ }^{1}$ Consiste num sistema de distinções visíveis e invisíveis, sendo que as invisíveis fundamentam as visíveis. As distinções invisíveis são estabelecidas através de linhas radicais que dividem a realidade social em dois universos distintos: o universo "deste lado da linha" e o universo "do outro lado da linha”. A divisão é tal que "o outro lado da linha" desaparece enquanto realidade, torna-se

\footnotetext{
* Este trabalho foi apresentado em diferentes versões no Fernand Braudel Center, Universidade de New York em Binghamton, na Universidade de Glasgow, na Universidade de Victoria, na Universidade de Wisconsin-Madison e na Universidade de Coimbra. Gostaria de agradecer a Gavin Anderson, Alison Phipps, Emilios Christodoulidis, David Schneiderman, Claire Cutler, Upendra Baxi, James Tully, Len Kaplan, Marc Galanter, Neil Komesar, Joseph Thome, Javier Couso, Jeremy Webber, Rebecca Johnson, e John Harrington, António Sousa Ribeiro, Margarida Calafate Ribeiro, Joaquin Herrera Flores, Conceição Gomes e João Pedroso pelos seus comentários. Maria Paula Meneses, além de comentar o texto, auxiliou-me no trabalho de pesquisa pelo que the estou muito grato. Este trabalho não teria sido possível sem a inspiração das longas conversas com Maria Irene Ramalho sobre as relações entre as ciências sociais e as ciências humanas. Foi ela também a responsável pela preparação da versão inglesa.

${ }^{1}$ Não pretendo que o pensamento moderno ocidental seja a única forma de pensamento abissal. Pelo contrário, é muito provável que existam, ou tenham existido, formas de pensamento abissal fora do Ocidente. Não é meu propósito analisá-las neste texto. Defendo apenas que, abissais ou não, as formas de pensamento não-ocidental têm sido tratadas de um modo abissal pelo pensamento moderno ocidental. Também não trato aqui do pensamento pré-moderno ocidental nem das versões do pensamento moderno ocidental marginalizadas ou suprimidas por se oporem às versões hegemónicas, as únicas de que me ocupo neste ensaio.
} 
inexistente, e é mesmo produzido como inexistente. Inexistência significa não existir sob qualquer forma de ser relevante ou compreensível. ${ }^{2}$ Tudo aquilo que é produzido como inexistente é excluído de forma radical porque permanece exterior ao universo que a própria concepção aceite de inclusão considera como sendo o Outro. A característica fundamental do pensamento abissal é a impossibilidade da co-presença dos dois lados da linha. Este lado da linha só prevalece na medida em que esgota o campo da realidade relevante. Para além dela há apenas inexistência, invisibilidade e ausência não-dialéctica. Para dar um exemplo baseado no meu próprio trabalho, tenho vindo a caracterizar a modernidade ocidental como um paradigma fundado na tensão entre a regulação e a emancipação social. ${ }^{3}$ Esta distinção visível fundamenta todos os conflitos modernos, tanto no relativo a factos substantivos como no plano dos procedimentos. Mas subjacente a esta distinção existe uma outra, invisível, na qual a anterior se funda. Esta distinção invisível é a distinção entre as sociedades metropolitanas e os territórios coloniais. De facto, a dicotomia regulação/emancipação apenas se aplica a sociedades metropolitanas. Seria impensável aplicá-la aos territórios coloniais. Nestes aplica-se uma outra dicotomia, a dicotomia apropriação/violência que, por seu turno, seria inconcebível aplicar deste lado da linha.

Sendo que os territórios coloniais constituíam lugares impensáveis para o desenvolvimento do paradigma da regulação/emancipação, o facto de este paradigma lhes não ser aplicável não comprometeu a sua universalidade. O pensamento abissal moderno salienta-se pela sua capacidade de produzir e radicalizar distinções. Contudo, por mais radicais que sejam estas distinções e por mais dramáticas que possam ser as consequências de estar de um ou do outro dos lados destas distinções, elas têm em comum o facto de pertencerem a este lado da linha e de se combinarem para tornar invisível a linha abissal na qual estão fundadas. As distinções intensamente visíveis que estruturam a realidade social deste lado da linha baseiam-se na invisibilidade das distinções entre este e o outro lado da linha.

\footnotetext{
${ }^{2}$ Sobre a sociologia das ausências como crítica à produção de realidade não existente pelo pensamento hegemónico, ver Santos, 2000, 2003b, 2004, 2006b e 2006c.

${ }^{3}$ Esta tensão representa o outro lado da discrepância moderna entre as experiências actuais e as expectativas quanto ao futuro, também expressas no mote positivista da "ordem e progresso". O pilar da regulação social é constituído pelo princípio do Estado, princípio da comunidade e princípio do mercado, enquanto o pilar da emancipação consiste nas três lógicas da racionalidade: a racionalidade estético-expressiva das artes e literatura, a racionalidade instrumental-cognitiva da ciência e tecnologia e a racionalidade moral-prática da ética e do direito (Santos, 1995: 2). Ver também Santos, 2000 e 2002.
} 
O conhecimento e o direito modernos representam as manifestações mais bem conseguidas do pensamento abissal. Dão-nos conta das duas principais linhas abissais globais dos tempos modernos, as quais, embora distintas e operando de forma diferenciada, são mutuamente interdependentes. Cada uma cria um subsistema de distinções visíveis e invisíveis de tal forma que as invisíveis se tornam o fundamento das visíveis. No campo do conhecimento, o pensamento abissal consiste na concessão à ciência moderna do monopólio da distinção universal entre o verdadeiro e o falso, em detrimento de dois conhecimentos alternativos: a filosofia e a teologia. O carácter exclusivo deste monopólio está no cerne da disputa epistemológica moderna entre as formas científicas e não-científicas de verdade. Sendo certo que a validade universal da verdade científica é, reconhecidamente, sempre muito relativa, dado o facto de poder ser estabelecida apenas em relação a certos tipos de objectos em determinadas circunstâncias e segundo determinados métodos, como é que ela se relaciona com outras verdades possíveis que podem inclusivamente reclamar um estatuto superior, mas não podem ser estabelecidas de acordo com o método científico, como é o caso da razão como verdade filosófica e da fé como verdade religiosa ${ }^{4}$ Estas tensões entre a ciência, a filosofia e a teologia têm sido sempre altamente visíveis, mas como defendo, todas elas têm lugar deste lado da linha. A sua visibilidade assenta na invisibilidade de formas de conhecimento que não encaixam em nenhuma destas formas de conhecer. Refiro-me aos conhecimentos populares, leigos, plebeus, camponeses, ou indígenas do outro lado da linha. Eles desaparecem como conhecimentos relevantes ou comensuráveis por se encontrarem para além do universo do verdadeiro e do falso. É inimaginável aplicar-lhes não só a distinção científica entre verdadeiro e falso, mas também as verdades inverificáveis da filosofia e da teologia que constituem o outro conhecimento aceitável deste lado da linha. ${ }^{5}$ Do outro lado da linha, não há conhecimento real; existem crenças, opiniões, magia, idolatria, entendimentos intuitivos ou subjectivos, que, na melhor das hipóteses, podem tornar-se objectos ou matéria-prima para a inquirição científica. Assim, a linha visível que separa a ciência dos seus "outros" modernos está assente na linha abissal invisível que separa, de um lado, ciência, filosofia e teologia e, do outro, conhecimentos tornados incomensuráveis e incompreen-

\footnotetext{
${ }^{4}$ Embora de formas muito distintas, Pascal, Kierkegaard e Nietzsche foram os filósofos que mais aprofundadamente analisaram, e viveram, as antinomias contidas nesta questão. Mais recentemente, merecem menção Karl Jaspers (1952, 1986, 1995) e Stephen Toulmin (2001).

5 Para uma visão geral dos debates recentes sobre as relações entre a ciência e outros conhecimentos, veja-se Santos, Meneses e Nunes, 2004. Ver também Santos 1995: 7-55.
} 
síveis por não obedecerem, nem aos critérios científicos de verdade, nem aos dos conhecimentos, reconhecidos como alternativos, da filosofia e da teologia.

No campo do direito moderno, este lado da linha é determinado por aquilo que conta como legal ou ilegal de acordo com o direito oficial do Estado ou com o direito internacional. O legal e o ilegal são as duas únicas formas relevantes de existência perante a lei, e, por esta razão, a distinção entre ambos é uma distinção universal. Esta dicotomia central deixa de fora todo um território social onde ela seria impensável como princípio organizador, isto é, o território sem lei, fora da lei, o território do a-legal, ou mesmo do legal e ilegal de acordo com direitos não oficialmente reconhecidos. ${ }^{6}$ Assim, a linha abissal invisível que separa o domínio do direito do domínio do não-direito fundamenta a dicotomia visível entre o legal e o ilegal que deste lado da linha organiza o domínio do direito.

Em cada um dos dois grandes domínios - a ciência e o direito - as divisões levadas a cabo pelas linhas globais são abissais no sentido em que eliminam definitivamente quaisquer realidades que se encontrem do outro lado da linha. Esta negação radical de co-presença fundamenta a afirmação da diferença radical que, deste lado da linha, separa o verdadeiro do falso, o legal do ilegal. O outro lado da linha compreende uma vasta gama de experiências desperdiçadas, tornadas invisíveis, tal como os seus autores, e sem uma localização territorial fixa. Em verdade, como anteriormente referi, originalmente existiu uma localização territorial e esta coincidiu historicamente com um território social específico: a zona colonial. ${ }^{7}$ Tudo o que não pudesse ser pensado em termos de verdadeiro ou falso, de legal ou ilegal, ocorria na zona colonial. A este respeito, o direito moderno parece ter alguma precedência histórica sobre a ciência na criação do pensamento abissal. De facto, contrariamente ao pensamento jurídico convencional, foi a linha global que separava o Velho Mundo do Novo Mundo que tornou possível a emergência, deste lado da linha, do direito moderno e, em particular, do direito internacional moderno. ${ }^{8}$

\footnotetext{
${ }^{6}$ Em Santos, 2002, analiso em detalhe a natureza do direito moderno e o tópico do pluralismo jurídico (a coexistência de mais de um sistema jurídico no mesmo espaço geopolítico).

${ }_{7}$ Neste trabalho, tomo por assente a ligação íntima entre capitalismo e colonialismo. Veja-se, entre outros, Williams, 1994 (publicado originalmente em 1944); Arendt, 1951; Fanon, 1967; Horkheimer e Adorno, 1972; Wallerstein, 1974; Dussel, 1992; Mignolo, 1995; Quijano, 2000.

${ }^{8}$ Assim, o imperialismo é constitutivo do Estado moderno. Ao contrário do que afirmam as teorias convencionais do direito internacional, este não é produto de um Estado moderno pré-existente. O Estado moderno, o direito internacional e o constitucionalismo nacional e global são produtos do mesmo processo histórico imperial. Ver Koskenniemi, 2002; Anghie, 2005; e Tully, 2007.
} 
A primeira linha global moderna foi, provavelmente, o Tratado de Tordesilhas entre Portugal e Espanha (1494), ${ }^{9}$ mas as verdadeiras linhas abissais emergem em meados do século XVI com as amity lines (linhas de amizade). ${ }^{10}$ O seu carácter abissal manifesta-se no elaborado trabalho cartográfico investido na sua definição, na extrema precisão exigida a cartógrafos, fabricantes de globos terrestres e pilotos, no policiamento vigilante e nas duras punições das violações. Na sua constituição moderna, o colonial representa, não o legal ou o ilegal, mas antes o sem lei. Uma máxima que então se populariza, "para além do Equador não há pecados", ecoa no passo famoso dos Pensamentos de Pascal, escritos em meados do século XVII: "Três graus de latitude alteram toda a jurisprudência e um meridiano determina o que é verdadeiro... É um tipo peculiar de justiça cujos limites são demarcados por um rio, verdadeiro neste lado dos Pirinéus e falso no outro" (1966: 46). De meados do século XVI em diante, o debate jurídico e político entre os estados europeus a propósito do Novo Mundo concentra-se na linha global, isto é, na determinação do colonial, não na ordenação interna do colonial. Pelo contrário, o colonial é o estado de natureza onde as instituições da

\footnotetext{
9 A definição das linhas globais ocorre gradualmente. Segundo Carl Schmitt (2003: 91), as linhas cartográficas do século XV pressupunham ainda uma ordem espiritual global vigente de ambos os lados da divisão - a Respublica Christiana, simbolizada pelo Papa. Isto explica as dificuldades enfrentadas por Francisco Vitoria, o grande teólogo e jurista espanhol do século XVI, para justificar a ocupação de terras nas Américas. Vitoria pergunta se a descoberta é suficiente como título jurídico de posse da terra. A sua resposta é muito complexa, não só por ser formulada em estilo aristotélico, mas sobretudo porque Vitoria não concebe qualquer resposta convincente que não parta da premissa da superioridade europeia. Este facto, contudo, não confere qualquer direito moral ou positivo sobre as terras ocupadas. Segundo Vitoria, nem mesmo a superioridade civilizacional dos Europeus é suficiente como base de um direito moral. Para Vitoria, a conquista podia servir apenas de fundamento a um direito reversível à terra, a jura contraria, nas suas palavras. Isto é, a questão da relação entre a conquista e o direito à terra deve ser colocada inversamente: se os Índios tivessem descoberto e conquistado os Europeus, teriam eles igual direito a ocupar as terras? A justificação de Vitoria para a ocupação de terras assenta ainda na ordem cristã medieval, na missão atribuída pelo Papa aos reis espanhol e português, e no conceito de guerra justa (Schmitt, 2003: 101-125; ver também Anghie, 2005: 13-31). A laboriosa argumentação de Vitoria reflecte o grau de cuidado da Coroa que, ao tempo, se preocupava mais com a legitimação dos direitos de propriedade do que com a soberania sobre o Novo Mundo. Ver também Pagden, 1990: 15.

${ }_{10}$ Do século XVI em diante, as linhas cartográficas, as chamadas amity lines - a primeira das quais poderá ter emergido em resultado do Tratado de Cateau-Cambresis (1559) entre a Espanha e a França - abandonaram a ideia de uma ordem comum global e estabeleceram uma dualidade abissal entre os territórios deste lado da linha e os territórios do outro lado da linha. Deste lado da linha, vigoram a verdade, a paz e a amizade; do outro lado da linha, a lei do mais forte, a violência e a pilhagem. O que quer que ocorra do outro lado da linha não está sujeito aos mesmos princípios éticos e jurídicos que se aplicam deste lado. Não poderá, portanto, dar origem ao tipo de conflitos que a violação de tais princípios causaria se ocorresse deste lado da linha. Esta dualidade permitiu, por exemplo, aos reis católicos de França manterem, deste lado da linha, uma aliança com os reis católicos de Espanha e, ao mesmo tempo, aliarem-se aos piratas que, do outro lado da linha, atacavam os barcos espanhóis.
} 
sociedade civil não têm lugar. Hobbes refere-se explicitamente aos "povos selvagens em muitos lugares da América" como exemplares do estado de natureza (1985: 187), e Locke pensa da mesma forma ao escrever em Sobre o Governo Civil: "No princípio todo o mundo foi América" (1946: \$49).

O colonial constitui o grau zero a partir do qual são construídas as modernas concepções de conhecimento e direito. As teorias do contrato social dos séculos XVII e XVIII são tão importantes pelo que dizem como pelo que silenciam. O que dizem é que os indivíduos modernos, ou seja, os homens metropolitanos, entram no contrato social abandonando o estado de natureza para formarem a sociedade civil. ${ }^{11} \mathrm{O}$ que silenciam é que, desta forma, se cria uma vasta região do mundo em estado de natureza, um estado de natureza a que são condenados milhões de seres humanos sem quaisquer possibilidades de escaparem por via da criação de uma sociedade civil. A modernidade ocidental, em vez de significar o abandono do estado de natureza e a passagem à sociedade civil, significa a coexistência da sociedade civil com o estado de natureza, separados por uma linha abissal com base na qual o olhar hegemónico, localizado na sociedade civil, deixa de ver e declara efectivamente como não-existente o estado de natureza. O presente que vai sendo criado do outro lado da linha é tornado invisível ao ser reconceptualizado como o passado irreversível deste lado da linha. O contacto hegemónico converte simultaneidade em não-contemporaneidade. Inventa passados para dar lugar a um futuro único e homogéneo. Assim, o facto de os princípios legais vigentes na sociedade civil deste lado da linha não se aplicarem do outro lado da linha não compromete de forma alguma a sua universalidade.

A mesma cartografia abissal é constitutiva do conhecimento moderno. Mais uma vez, a zona colonial é, par excellence, o universo das crenças e dos comportamentos incompreensíveis que de forma alguma podem considerar-se conhecimento, estando, por isso, para além do verdadeiro e do falso. O outro lado da linha alberga apenas práticas incompreensíveis, mágicas ou idolátricas. A completa estranheza de tais práticas conduziu à própria negação da natureza humana dos seus agentes. Com base nas suas refinadas concepções de humanidade e de dignidade humana, os humanistas dos séculos XV e XVI chegaram à conclusão de que os selvagens eram sub-humanos. A questão era: os índios têm alma? Quando o Papa Paulo III respondeu afirmativamente na bula Sublimis Deus, de 1537, fê-lo concebendo a alma dos povos selvagens como um receptáculo vazio, uma anima

${ }^{11}$ Sobre as diferentes concepções do contrato social, ver Santos, 2002: 30-39. 
nullius, muito semelhante à terra nullius, ${ }^{12} \mathrm{o}$ conceito de vazio jurídico que justificou a invasão e ocupação dos territórios indígenas. Com base nestas concepções abissais de epistemologia e legalidade, a universalidade da tensão entre a regulação e a emancipação, aplicada deste lado da linha, não entra em contradição com a tensão entre apropriação e violência aplicada do outro lado da linha.

A apropriação e a violência tomam diferentes formas na linha abissal jurídica e na linha abissal epistemológica. Mas, em geral, a apropriação envolve incorporação, cooptação e assimilação, enquanto a violência implica destruição física, material, cultural e humana. Na prática, é profunda a interligação entre a apropriação e a violência. No domínio do conhecimento, a apropriação vai desde o uso de habitantes locais como guias $^{13}$ e de mitos e cerimónias locais como instrumentos de conversão, à pilhagem de conhecimentos indígenas sobre a biodiversidade, enquanto a violência é exercida através da proibição do uso das línguas próprias em espaços públicos, da adopção forçada de nomes cristãos, da conversão e destruição de símbolos e lugares de culto, e de todas as formas de discriminação cultural e racial.

No que toca ao direito, a tensão entre apropriação e violência é particularmente complexa devido à sua relação directa com a extracção de valor: tráfico de escravos e trabalho forçado, uso manipulador do direito e das autoridades tradicionais através do governo indirecto (indirect rule), pilhagem de recursos naturais, deslocação maciça de populações, guerras e tratados desiguais, diferentes formas de apartheid e assimilação forçada, etc. Enquanto a lógica da regulação/emancipação é impensável sem a distinção matricial entre o direito das pessoas e o direito das coisas, a lógica da apropriação/violência reconhece apenas o direito das coisas, sejam elas humanas ou não. A versão extrema deste tipo de direito, irreconhecível deste lado da linha, é o direito do "Estado Livre do Congo" imposto pelo Rei Leopoldo II da Bélgica. ${ }^{14}$

Existe, portanto, uma cartografia moderna dual: a cartografia jurídica e a cartografia epistemológica. O outro lado da linha abissal é um universo

\footnotetext{
${ }^{12}$ De acordo com a Bula, "os Índios eram verdadeiros homens e... não eram capazes de entender a fé Católica mas, de acordo com as nossas informações, desejam ardentemente recebê-la". "Sublimis Deus" encontra-se em http://www.papalencyclicals.net/Paul03/p3subli.htm (acedido em 22 de Setembro, 2006).

${ }^{13}$ Como no caso famoso de Ibn Majid, um experiente piloto que indicou a Vasco da Gama o caminho marítimo de Mombaça à Índia (Ahmad, 1971). Outros exemplos podem encontrar-se em Burnett, 2002.

${ }_{14}$ Diferentes perspectivas sobre esta "colónia privada" e sobre o Rei Leopoldo podem encontrar-se em Emerson, 1979; Hochschild, 1999; Dumoulin, 2005; Hasian, 2002:89-112.
} 
que se estende para além da legalidade e ilegalidade, para além da verdade e da falsidade..$^{15}$ Juntas, estas formas de negação radical produzem uma ausência radical, a ausência de humanidade, a sub-humanidade moderna. Assim, a exclusão torna-se simultaneamente radical e inexistente, uma vez que seres sub-humanos não são considerados sequer candidatos à inclusão social. ${ }^{16} \mathrm{~A}$ humanidade moderna não se concebe sem uma sub-humanidade moderna. ${ }^{17}$ A negação de uma parte da humanidade é sacrificial, na medida em que constitui a condição para a outra parte da humanidade se afirmar enquanto universal. ${ }^{18}$

A minha tese é que esta realidade é tão verdadeira hoje como era no período colonial. O pensamento moderno ocidental continua a operar mediante linhas abissais que dividem o mundo humano do sub-humano, de tal forma que princípios de humanidade não são postos em causa por práticas desumanas. As colónias representam um modelo de exclusão radical que permanece actualmente no pensamento e práticas modernas ocidentais tal como aconteceu no ciclo colonial. Hoje, como então, a criação e ao mesmo tempo a negação do outro lado da linha fazem parte integrante de princípios e práticas hegemónicos. Actualmente, Guantánamo representa uma das manifestações mais grotescas do pensamento jurídico abissal, da criação do outro lado da fractura enquanto um não-território em termos jurídicos e políticos, um espaço impensável para o primado da lei, dos direitos humanos e da democracia. ${ }^{19}$ Porém, seria um erro considerá-lo uma excepção. Existem muitos Guantánamos, desde o Iraque à Palestina e a Darfur. Mais do que isso, existem milhões de Guantánamos nas discriminações sexuais e raciais quer na esfera pública, quer na privada, nas zonas

\footnotetext{
${ }_{15}$ A profunda dualidade do pensamento abissal e a incomensurabilidade entre os termos dessa dualidade foram implementadas pelos monopólios bem policiados do conhecimento e do direito com uma poderosa base institucional - universidades, centros de investigação, escolas de direito e profissões jurídicas - e pela sofisticada linguagem tecnológica da ciência e da jurisprudência. ${ }^{16}$ A suposta externalidade do outro lado da linha é, de facto, a consequência da sua pertença ao pensamento abissal: como fundação e como negação da fundação.

${ }_{17}$ Fanon denuncia esta negação da humanidade com insuperável lucidez (Fanon, 1963, 1967). $\mathrm{O}$ radicalismo da negação fundamenta a defesa que Fanon faz da violência como uma dimensão intrínseca da revolta anti-colonial. Embora partilhassem uma luta comum, Fanon e Gandhi divergiram a este respeito e essa divergência deve ser objecto de uma reflexão cuidada, particularmente pelo facto de se tratar de dois dos mais importantes pensadores-activistas do século passado. Ver Federici, 1994, e Kebede, 2001.

${ }^{18}$ Esta negação fundamental permite por um lado, que tudo o que é possível se transforme na possibilidade de tudo, e por outro, que a criatividade exaltadora do pensamento abissal trivialize facilmente o preço da sua destrutividade.

19 Sobre Guantánamo e tópicos relacionados ver, entre muitos outros, McCormack, 2004; Amann, 2004a, 2004b; Human Rights Watch, 2004; Sadat, 2005; Steyn, 2004; Borelli, 2005; Dickinson, 2005; Van Bergen e Valentine, 2006.
} 
selvagens das megacidades, nos guetos, nas sweatshops, nas prisões, nas novas formas de escravatura, no tráfico ilegal de órgãos humanos, no trabalho infantil e na exploração da prostituição.

Neste texto, começo por argumentar que a tensão entre regulação e emancipação continua a coexistir com a tensão entre apropriação e violência, e de tal maneira que a universalidade da primeira tensão não é questionada pela existência da segunda. Em segundo lugar, argumento que as linhas abissais continuam a estruturar o conhecimento e o direito modernos e que são constitutivas das relações e interacções políticas e culturais que o Ocidente protagoniza no interior do sistema mundial. Em suma, a minha tese é que a cartografia metafórica das linhas globais sobreviveu à cartografia literal das amity lines que separavam o Velho do Novo Mundo. A injustiça social global está, desta forma, intimamente ligada à injustiça cognitiva global. A luta pela justiça social global deve, por isso, ser também uma luta pela justiça cognitiva global. Para ser bem sucedida, esta luta exige um novo pensamento, um pensamento pós-abissal.

\section{A divisão abissal entre regulação/emancipação e apropriação/violência}

A permanência das linhas abissais globais ao longo de todo o período moderno não significa que estas se tenham mantido fixas. Historicamente, as linhas globais que dividem os dois lados têm vindo a deslocar-se. Mas, em cada momento histórico, elas são fixas e a sua posição é fortemente vigiada e guardada, tal como sucedia com as linhas de amizade. Nos últimos sessenta anos, as linhas globais sofreram dois abalos tectónicos. O primeiro teve lugar com as lutas anticoloniais e os processos de independência das antigas colónias. ${ }^{20} \mathrm{O}$ outro lado da linha sublevou-se contra a exclusão radical à medida que os povos que haviam sido sujeitos ao paradigma da apropriação/violência se organizaram e reclamaram o direito à inclusão no paradigma da regulação/emancipação (Fanon, 1963, 1967; Nkrumah, 1965; Cabral, 1979; Gandhi, 1951, 1956). Durante algum tempo, o paradigma da apropriação/violência parecia ter chegado ao fim, e do mesmo modo também a divisão abissal entre este lado da linha e o outro lado da linha. Cada uma das duas linhas globais (a epistemológica e a jurídica) pareciam estar a movimentar-se de acordo com a sua própria lógica, mas ambas na mesma direcção: os seus movimentos pareciam convergir na retracção e, finalmente, na eliminação do outro lado da linha. Contudo, não foi isto que aconteceu,

${ }^{20}$ Em vésperas da Segunda Guerra Mundial, as colónias e ex-colónias cobriam cerca de 85\% da superfície do globo. 
como mostram a teoria da dependência, a teoria do sistema do mundo moderno, e os estudos pós-coloniais. ${ }^{21}$

Neste texto, faço incidir a minha atenção sobre o segundo abalo tectónico das linhas abissais. Este tem vindo a decorrer desde os anos de 1970 e 1980 e segue na direcção oposta. Desta feita, as linhas globais estão de novo em movimento, mas de uma forma tal que o outro lado da linha parece estar a expandir-se, enquanto este lado da linha parece estar a encolher. A lógica da apropriação/violência tem vindo a ganhar força em detrimento da lógica da regulação/emancipação. Numa extensão tal que o domínio da regulação/emancipação não só está a encolher, como também está a ficar contaminado internamente pela lógica da apropriação/violência.

A complexidade deste movimento é difícil de destrinçar na medida em que se desenrola ante os nossos olhos, que não conseguem abstrair-se do facto de estarem deste lado da linha e de olharem de dentro para fora. Para captar a totalidade do que está a ocorrer é necessário um esforço enorme de descentramento. Nenhum estudioso pode fazê-lo sozinho, como indivíduo. Baseado num esforço colectivo para desenvolver uma epistemologia do Sul, ${ }^{22}$ a minha proposta é que este movimento é composto de um movimento principal e de um contra-movimento subalterno. Denomino o movimento principal de regresso do colonial e do colonizador, e o contra-movimento, de cosmopolitismo subalterno.

Em primeiro lugar, o regresso do colonial e o regresso do colonizador. Aqui, o colonial é uma metáfora daqueles que entendem as suas experiências de vida como ocorrendo do outro lado da linha e se rebelam contra isso. O regresso do colonial é a resposta abissal ao que é percebido como uma intromissão ameaçadora do colonial nas sociedades metropolitanas. Este regresso assume três formas principais: o terrorista, ${ }^{23} \mathrm{o}$ imigrante indo-

\footnotetext{
${ }^{21}$ As origens múltiplas e subsequentes variações destes debates podem encontrar-se em Memmi, 1965; Dos Santos, 1971; Cardoso e Faletto, 1969; Frank, 1969; Rodney, 1972; Wallerstein, 1974, 2004; Bambirra, 1978; Dussell, 1995; Escobar, 1995; Chew e Denemark, 1996; Spivak, 1999; Césaire, 2000; Mignolo, 2000; Grosfoguel, 2000; Afzal-Khan e Sheshadri-Crooks, 2000; Mbembe, 2001; Dean e Levi, 2003.

${ }^{22}$ Entre 1999 e 2002, realizei um projecto internacional sobre "A Reinvenção da Emancipação Social" que envolveu 60 investigadores de 6 países (África do Sul, Brasil, Colômbia, Índia, Moçambique e Portugal). Os resultados principais da investigação estão publicados em sete volumes. Estão publicados em português os cinco primeiros; em espanhol, Santos (org.), 2004b; em inglês, Santos (org.), 2005a, 2006 e 2007; e em italiano, Santos (org.), 2003c, 2005b. Sobre as implicações epistemológicas deste projecto ver Santos (org.), 2003a e Santos, 2004. Sobre as ligações entre este projecto e o Fórum Social Mundial, ver Santos, 2005 e 2006c.

${ }_{23}$ Entre outros, ver Harris, 2003; Kanstroom, 2003; Sekhon, 2003; C. Graham, 2005; N. Graham 2005; Scheppele, 2004a, 2004b, 2006; Guiora, 2005.
} 
cumentado ${ }^{24}$ e o refugiado. ${ }^{25}$ De formas distintas, cada um deles traz consigo a linha abissal global que define a exclusão radical e inexistência jurídica. Por exemplo, em muitas das suas disposições, a nova vaga de legislação anti-terrorista e de imigração segue a lógica reguladora do paradigma da apropriação/violência. ${ }^{26} \mathrm{O}$ regresso do colonial não significa necessariamente a sua presença física nas sociedades metropolitanas. Basta que possua uma ligação relevante com elas. No caso do terrorista, esta ligação pode ser estabelecida pelos serviços secretos. No caso do trabalhador imigrante indocumentado, basta que seja contratado por uma das muitas centenas de sweatshops que operam no Sul global ${ }^{27}$ subcontratadas por corporações metropolitanas multinacionais. No caso dos refugiados, a ligação relevante é estabelecida pelo seu pedido de obtenção do estatuto de refugiado numa dada sociedade metropolitana.

O colonial que regressa é, de facto, um novo colonial abissal. Desta feita, o colonial retorna não só aos antigos territórios coloniais, mas também às sociedades metropolitanas. Aqui reside a grande transgressão, pois o colonial do período colonial clássico em caso algum poderia entrar nas sociedades metropolitanas a não ser por iniciativa do colonizador (como escravo, por exemplo). Os espaços metropolitanos que se encontravam demarcados desde o início da modernidade ocidental deste lado da linha estão a ser invadidos ou trespassados pelo colonial. Mais ainda, o colonial demonstra um nível de mobilidade imensamente superior à mobilidade dos escravos em fuga (David, 1924; Tushnet, 1981: 169-188). Nestas circunstâncias, o abissal metropolitano vê-se confinado a um espaço cada vez mais limitado e reage remarcando a linha abissal. Na sua perspectiva, a nova intromissão do colonial tem de ser confrontada com a lógica ordenadora da apropriação/violência. Chegou ao fim o tempo de uma divisão clara entre o Velho e o Novo Mundo, entre o metropolitano e o colonial. A linha tem de ser

\footnotetext{
${ }^{24}$ Ver Sassen, 1999; Miller, 2002; De Genova, 2002; Kanstroom, 2004; Hansen e Stepputat, 2004; Wishnie, 2004; Taylor, 2004; Silverstein, 2005; Passel, 2005. Para uma visão mais radical sobre este tema, ver Buchanan, 2006.

${ }^{25}$ Baseado no Orientalismo analisado por Edward Said (1978), Akram (2000) identifica uma nova forma de estereótipo, a que chama neo-Orientalismo e que afecta a avaliação metropolitana dos pedidos de asilo e refúgio por parte de pessoas provenientes do mundo árabe ou muçulmano. Ver também Akram, 1999; Menefee, 2004; Bauer, 2004; Cianciarulo, 2005; Akram e Karmely, 2005. ${ }^{26}$ Sobre as implicações da nova vaga anti-terrorista e das novas leis de imigração, ver os artigos citados nas notas 23, 24, e 25 e também Immigrant Rights Clinic, 2001; Chang, 2001; Whitehead e Aden, 2002; Zelman, 2002; Lobel, 2002; Roach, 2002 (sobre o caso canadiano); Van de Linde et al., 2002 (sobre alguns países europeus); Miller, 2002; Emerton, 2004 (sobre a Austrália); Boyne, 2004 (sobre a Alemanha); Krishnan, 2004 (sobre a Índia); Barr, 2004; N. Graham, 2005.

${ }^{27}$ Refiro-me aqui às regiões periféricas e semiperiféricas e aos países do sistema mundo moderno, que foram denominados de Terceiro Mundo, após a Segunda Guerra Mundial (Santos, 1995: 506-519).
} 
desenhada a uma distância tão curta quanto o necessário para garantir a segurança. $\mathrm{O}$ que costumava pertencer inequivocamente a este lado da linha é agora um território confuso atravessado por uma linha abissal sinuosa. O muro da segregação israelita na Palestina (Tribunal Internacional de Justiça, 2005) e a categoria de "combatente inimigo ilegal" (Dörmann, 2003; Harris, 2003; Kanstroom, 2003; Human Rights Watch, 2004; Gill e Sliedregt, 2005), criada pela administração dos EUA depois do 11 de Setembro, constituem possivelmente as metáforas mais adequadas da nova linha abissal e da cartografia confusa a que conduz.

Uma cartografia confusa não pode deixar de conduzir a práticas confusas. A regulação/emancipação é cada vez mais desfigurada pela presença e crescente pressão da apropriação/violência no seu interior. Contudo, nem a pressão nem o desfiguramento podem ser completamente percebidos, precisamente pelo facto de o outro lado da linha ter sido desde o início incompreensível como um território sub-humano. ${ }^{28}$ De formas distintas, o terrrorista e o trabalhador imigrante indocumentado são ambos ilustrativos da pressão da lógica da apropriação/violência e da inabilidade do pensamento abissal para se aperceber desta pressão como algo estranho à regulação/emancipação. Cada vez se torna mais evidente que a legislação antiterrorista já mencionada e que se encontra em promulgação em muitos países, seguindo a resolução do Conselho de Segurança das Nações Unidas ${ }^{29}$ e sob forte pressão da diplomacia dos EUA, esvazia o conteúdo civil e político dos direitos e garantias básicas das Constituições nacionais. Porque tudo isto ocorre sem uma suspensão formal destes direitos e garantias, estamos perante a emergência de uma nova forma de Estado, o Estado de excepção, que, contrariamente às antigas formas de Estado de sítio ou de Estado de emergência, restringe os direitos democráticos sob o pretexto da sua salvaguarda ou mesmo expansão. ${ }^{30}$

\footnotetext{
${ }^{28}$ Como exemplo, os profissionais do direito são solicitados a adaptar-se à pressão proveniente da reorganização da doutrina convencional, alterando regras de interpretação, redefinindo o objectivo dos princípios e hierarquias entre eles. Um exemplo revelador é o debate sobre a constitucionalidade da tortura entre Alan Dershowitz e os seus críticos. Ver Dershowitz, 2002, 2003a, 2003b; Posner, 2002; Kreimer, 2003; Strauss, 2004.

${ }^{29}$ Resolução 1566 do Conselho de Segurança das Nações Unidas. Esta resolução antiterrorismo foi aprovada a 8 de Outubro de 2004, na sequência da resolução 1373 que, por sua vez, foi aprovada como resposta aos ataques terroristas de 11 de Setembro nos EUA. Para uma análise detalhada do processo de aprovação da resolução 1566, ver Saul, 2005.

${ }^{30}$ Utilizo o conceito de Estado de excepção para expressar a condição jurídico-política na qual a erosão dos direitos civis e políticos ocorre abaixo do radar da Constituição, isto é, sem a suspensão desses direitos, como acontece quando é declarado o Estado de emergência. Ver Scheppele, 2004b; Agamben, 2004.
} 
De forma mais ampla, parece que a modernidade ocidental só poderá expandir-se globalmente na medida em que viole todos os princípios sobre os quais fez assentar a legitimidade histórica do paradigma da regulação/emancipação deste lado da linha. Direitos humanos são desta forma violados para poderem ser defendidos, a democracia é destruída para garantir a sua salvaguarda, a vida é eliminada em nome da sua preservação. Linhas abissais são traçadas tanto no sentido literal como metafórico. No sentido literal, estas são as linhas que definem as fronteiras como vedações ${ }^{31}$ e campos de morte, dividindo as cidades em zonas civilizadas (gated communities, ${ }^{32}$ em número sempre crescente) e zonas selvagens, e prisões entre locais de detenção legal e locais de destruição brutal e sem lei da vida. ${ }^{33}$

O outro lado do movimento principal em curso é o regresso do colonizador. Implica o ressuscitar de formas de governo colonial, tanto nas sociedades metropolitanas, agora incidindo sobre a vida dos cidadãos comuns, como nas sociedades anteriormente sujeitas ao colonialismo europeu. A expressão mais saliente deste movimento é o que eu designo como nova forma de governo indirecto. ${ }^{34}$ Emerge em muitas situações quando o Estado se retira da regulação social e os serviços públicos são privatizados. Poderosos actores não-estatais adquirem desta forma controlo sobre as vidas e o bem-estar de vastas populações, quer seja o controlo dos cuidados de saúde, da terra, da água potável, das sementes, das florestas ou da qualidade ambiental. A obrigação política que ligava o sujeito de direito ao Rechtsstaat, o Estado constitucional moderno, que tem prevalecido deste lado da linha, está a ser substituída por obrigações contratuais privadas e despolitizadas nas quais a parte mais fraca se encontra mais ao menos à mercê da parte mais forte. Esta forma de governo apresenta algumas semelhanças perturbadoras com o governo da apropriação/violência que prevaleceu do outro lado da linha.

\footnotetext{
${ }^{31}$ Um bom exemplo da lógica jurídica abissal subjacente à construção de uma vedação separando a fronteira dos EUA do México pode ver-se em Glon, 2005.

32 Sobre condomínios fechados, ver Blakely e Snyder, 1999; Low, 2003; Atkinson e Blandy, 2005; Coy, 2006.

33 Ver Amann, 2004a, 2004b; Brown, 2005. Um novo relatório pelo Comité Parlamentar Temporário Europeu sobre a actividade ilegal da CIA na Europa (Novembro, 2006) mostra como os governos europeus actuaram como facilitadores dos abusos da CIA, tais como a detenção secreta e a tortura. Estas operações à margem da lei envolveram 1.245 voos e aterragens de aviões da CIA na Europa (alguns deles envolvendo transporte de prisioneiros) e a criação de centros de detenção secreta na Polónia, Roménia e, provavelmente, também na Bulgária, Ucrânia, Macedónia e Kosovo.

${ }^{34} \mathrm{O}$ governo indirecto foi uma forma de política colonial europeia largamente praticada nas antigas colónias britânicas, onde as estruturas tradicionais de poder local, ou pelo menos uma parte delas, foram incorporadas na administração colonial estatal. Ver Lugard, 1929; Perham, 1934; Malinowski, 1945; Furnivall, 1948; Morris e Read, 1972; Mamdani, 1996, 1999.
} 
Tenho descrito esta situação como a ascensão do fascismo social, um regime social de relações de poder extremamente desiguais que concedem à parte mais forte o poder de veto sobre a vida e o modo de vida da parte mais fraca. Noutro lugar distingui cinco formas de fascismo social..$^{35}$ Aqui, refiro-me a três delas, as que mais claramente reflectem a pressão da lógica de apropriação/violência sobre a lógica da regulação/emancipação. A primeira forma é o fascismo do apartheid social. Trata-se da segregação social dos excluídos através de uma cartografia urbana dividida em zonas selvagens e zonas civilizadas. As zonas selvagens urbanas são as zonas do estado de natureza hobbesiano, zonas de guerra civil interna como em muitas megacidades em todo o Sul global. As zonas civilizadas são as zonas do contrato social e vivem sob a constante ameaça das zonas selvagens. Para se defenderem, transformam-se em castelos neofeudais, os enclaves fortificados que caracterizam as novas formas de segregação urbana (cidades privadas, condomínios fechados, gated communities, como mencionei acima). A divisão entre zonas selvagens e zonas civilizadas está a transformar-se num critério geral de sociabilidade, um novo espaço-tempo hegemónico que atravessa todas as relações sociais, económicas, políticas e culturais e que, por isso, é comum à acção estatal e à acção não-estatal.

A segunda forma é o fascismo contratual. Ocorre nas situações em que a diferença de poder entre as partes no contrato de direito civil (seja ele um contrato de trabalho ou um contrato de fornecimento de bens ou serviços) é de tal ordem que a parte mais fraca, vulnerabilizada por não ter alternativa ao contrato, aceita as condições que lhe são impostas pela parte mais poderosa, por mais onerosas e despóticas que sejam. O projecto neoliberal de transformar o contrato de trabalho num contrato de direito civil como qualquer outro configura uma situação de fascismo contratual. Como mencionei acima, esta forma de fascismo ocorre hoje frequentemente nas situações de privatização dos serviços públicos, da saúde, da segurança social, electricidade e água, etc. ${ }^{36}$ Nestes casos, o contrato social que presidiu à produção de serviços públicos no Estado-Providência e no Estado desenvolvimentista é reduzido ao contrato individual do consumo de serviços privatizados. À luz das deficiências por vezes chocantes da regulação pública,

\footnotetext{
35 Analiso em detalhe a emergência do fascismo social como consequência da quebra da lógica do contrato social em Santos, 2002: 447-458 e 2006b: 295-316.

${ }^{36}$ Um dos exemplos mais dramáticos é a privatização da água e as consequências sociais daí resultantes. Ver Bond, 2000, e Buhlungu et al., 2006 (para o caso da África do Sul); Oliveira Filho, 2002 (para o caso do Brasil); Olivera, 2005 e Flores, 2005 (para o caso da Bolívia); Bauer, 1998 (para o caso do Chile); Trawick, 2003 (para o caso do Peru); Castro, 2006 (para o caso do México). Sobre dois ou mais casos, ver Donahue e Johnston, 1998; Balanyá et al., 2005; Conca, 2005; Lopes, 2005. Ver também Klare, 2001; Hall, Lobina e de la Motte, 2005.
} 
esta redução preconiza a eliminação do âmbito contratual de aspectos decisivos para a protecção dos consumidores, aspectos que, por esta razão, se tornam extracontratuais e ficam à mercê da benevolência das empresas. Ao assumirem valências extracontratuais, as agências privadas de serviços assumem as funções de regulação social anteriormente exercidas pelo Estado. Este, implícita ou explicitamente, subcontrata a estas agências para-estatais o desempenho dessas funções e, ao fazê-lo sem a participação efectiva nem o controlo dos cidadãos, torna-se conivente com a produção social de fascismo contratual.

A terceira forma de fascismo social é o fascismo territorial. Existe sempre que actores sociais com forte capital patrimonial retiram ao Estado o controlo do território onde actuam ou neutralizam esse controlo, cooptando ou violentando as instituições estatais e exercendo a regulação social sobre os habitantes do território sem a participação destes e contra os seus interesses. Na maioria dos casos, estes constituem os novos territórios coloniais privados dentro de Estados que quase sempre estiveram sujeitos ao colonialismo europeu. Sob diferentes formas, a usurpação original de terras como prerrogativa do conquistador e a subsequente "privatização" das colónias encontram-se presentes na reprodução do fascismo territorial e, mais geralmente, nas relações entre terratenientes e camponeses sem terra. As populações civis residentes em zonas de conflitos armados encontram-se também submetidas ao fascismo territorial. ${ }^{37}$

O fascismo social é a nova forma do estado de natureza e prolifera à sombra do contrato social sob duas formas: pós-contratualismo e pré-contratualismo. O pós-contratualismo é o processo pelo qual grupos e interesses sociais até agora incluídos no contrato social são dele excluídos sem qualquer perspectiva de regresso: trabalhadores e classes populares são expulsos do contrato social através da eliminação dos seus direitos sociais e económicos, tornando-se assim populações descartáveis. O pré-contratualismo consiste no bloqueamento do acesso à cidadania a grupos sociais que anteriormente se consideravam candidatos à cidadania e tinham a expectativa fundada de a ela aceder: por exemplo, a juventude urbana habitante dos guetos das megacidades do Norte global e do Sul global. ${ }^{38}$

Como regime social, o fascismo social pode coexistir com a democracia política liberal. Em vez de sacrificar a democracia às exigências do capitalismo global, trivializa a democracia até ao ponto de não ser necessário, nem sequer conveniente, sacrificar a democracia para promover o capitalismo.

37 Para o caso da Colômbia, ver Santos e Garcia Villegas, 2001.

${ }^{38}$ Uma análise eloquente pode ser encontrada em Wilson, 1987. 
Trata-se, pois, de um fascismo pluralista e, por isso, de uma forma de fascismo que nunca existiu. De facto, é minha convicção que podemos estar a entrar num período em que as sociedades são politicamente democráticas e socialmente fascistas.

As novas formas de governo indirecto constituem também a segunda grande transformação da propriedade e do direito de propriedade da era moderna. A propriedade, e, mais especificamente, a propriedade dos territórios do Novo Mundo, foi, como mencionei inicialmente, o ponto chave subjacente ao estabelecimento das linhas abissais modernas. A primeira transformação teve lugar quando a propriedade sobre as coisas se expandiu, com o capitalismo, à propriedade sobre os meios de produção. Como Karl Renner (1965) tão bem descreveu, o proprietário das máquinas transformou-se no proprietário da força de trabalho dos trabalhadores que nelas operavam. O controlo sobre as coisas transformou-se em controlo sobre as pessoas. Claro que Renner desvalorizou o facto de esta transformação não ter ocorrido nas colónias, uma vez que o controlo sobre as pessoas era a forma original de controlo sobre as coisas, sendo que este último incluía tanto as coisas humanas, como as não-humanas. A segunda grande transformação da propriedade tem lugar, muito além da produção, quando a propriedade de serviços se torna uma forma de controlar as pessoas que deles necessitam para sobreviver. Usando a caracterização do governo colonial em África proposta por Mamdani (Mamdani, 1996: cap. 2) o novo governo indirecto promove uma forma de despotismo descentralizado. O despotismo descentralizado não choca com a democracia liberal, antes a torna progressivamente mais irrelevante para a qualidade de vida de populações cada vez vastas. Sob as condições do novo governo indirecto, o pensamento abissal moderno, mais do que regular os conflitos sociais entre cidadãos, é solicitado a suprimir conflitos sociais e a ratificar a impunidade deste lado da linha, como sempre sucedeu do outro lado da linha. Pressionado pela lógica da apropriação/violência, o próprio conceito de direito moderno - uma norma universalmente válida emanada do Estado e por ele imposta coercivamente se necessário - encontra-se assim em mudança. Como exemplo das mudanças conceptuais em curso está a emergir um novo tipo de direito que, eufemisticamente, se denomina "direito mole", soft law. ${ }^{39}$ Apresentado como a

\footnotetext{
${ }^{39}$ Uma vasta literatura tem vindo a ser produzida nos últimos anos teorizando e estudando empiricamente novas formas de governo da economia que assentam na colaboração entre actores não-estatais (firmas, organizações cívicas, ONGs, sindicatos, etc.) em lugar da regulação estatal de cima para baixo. Apesar da variedade de designações sob as quais os cientistas sociais e académicos do direito têm vindo a prosseguir esta abordagem, a ênfase recaí mais na "moleza" do que na dureza, na obediência voluntária mais do que na imposição: "regulação responsiva" (Ayres e Braithwaite, 1992), "lei pós-regulatória" (Teubner, 1986), "lei mole" (Snyder, 1993, 2002; Trubek e Mosher, 2003;
} 
manifestação mais benevolente do ordenamento regulação/emancipação, traz consigo a lógica da apropriação/violência sempre que estejam envolvidas relações muito desiguais de poder. Trata-se de um direito cujo cumprimento é voluntário. Sem surpresa, tem vindo a ser usado, entre outros domínios sociais, no campo das relações capital/trabalho, e a sua versão mais conseguida são os códigos de conduta cuja adopção tem sido recomendada às multinacionais metropolitanas na subcontratação de serviços às "suas" sweatshops em todo o mundo. ${ }^{40} \mathrm{~A}$ plasticidade da soft law apresenta semelhanças intrigantes com o direito colonial, cuja aplicação dependia mais da vontade do colonizador do que de qualquer outra coisa. ${ }^{41}$ As relações sociais que regula são, se não um novo estado de natureza, uma zona intermédia entre o estado de natureza e a sociedade civil, onde o fascismo social prolifera e floresce.

Em suma, o pensamento abissal moderno, que, deste lado da linha, tem vindo a ser chamado para regular as relações entre cidadãos e entre estes e o Estado, é agora chamado, nos domínios sociais sujeitos uma maior pressão por parte da lógica da apropriação/violência, a lidar com os cidadãos como se fossem não-cidadãos, e com não-cidadãos como se se tratasse de perigosos selvagens coloniais. Como o fascismo social coexiste com a democracia liberal, o Estado de excepção coexiste com a normalidade constitucional, a sociedade civil coexiste com o estado de natureza, o governo indirecto coexiste com o primado do direito. Longe de constituir a perversão de alguma regra normal, fundadora, este estado de coisas é o projecto original da moderna epistemologia e legalidade, mesmo que a linha abissal que desde o primeiro momento distinguiu o metropolitano do colonial se tenha deslocado, transformando o colonial numa dimensão interna do metropolitano.

\section{Cosmopolitismo subalterno}

À luz do que foi dito anteriormente, ficamos com a ideia de que, a menos que se defronte com uma resistência activa, o pensamento abissal continuará a auto-reproduzir-se, por mais excludentes que sejam as práticas que origina. Assim, a resistência política deve ter como postulado a resistência epistemológica. Como foi dito inicialmente, não existe justiça social global

\footnotetext{
Trubek e Trubek, 2005; Morth, 2004), “experimentalismo democrático” (Dorf e Sabel 1998; Unger 1998), "governação cooperativa” (Freeman, 1997), "regulação outsourced" (O’Rourke, 2003) ou simplesmente "governação" (Mac Neil, Sargent e Swan 2000; Nye e Donahue, 2000). Para uma crítica, ver Santos e Rodriguez-Garavito 2005: 1-26 e 29-63; Rodriguez-Garavito, 2005: 64-91.

40 Ver Rodriguez-Garavito, 2005, e a bibliografia aí citada.

${ }^{41}$ Este tipo de lei é eufemisticamente denominada soft por ser soft com aqueles cujo comportamento empreendedor era suposto regular (empregadores) e dura com aqueles que sofrem as consequências do seu não-cumprimento (trabalhadores).
} 
sem justiça cognitiva global. Isto significa que a tarefa crítica que se avizinha não pode ficar limitada à geração de alternativas. Ela requer, de facto, um pensamento alternativo de alternativas. É preciso um novo pensamento, um pensamento pós-abissal. Será possível? Existirão as condições que, se devidamente aproveitadas, poderão dar-lhe uma chance? A investigação sobre estas condições explica a minha especial atenção ao contra-movimento que mencionei acima, resultante do abalo que as linhas abissais globais têm vindo a sofrer desde 1970 e 1980: movimento a que dei o nome de cosmopolitismo subalterno. ${ }^{42}$

O cosmopolitismo subalterno contém uma promessa real apesar de o seu carácter ser de momento claramente embrionário. De facto, para captá-lo é necessário realizar o que chamo sociologia das emergências (Santos, 2004). Esta consiste numa amplificação simbólica de sinais, pistas e tendências latentes que, embora dispersas, embrionárias e fragmentadas, apontam para novas constelações de sentido tanto no que respeita à compreensão como à transformação do mundo. O cosmopolitismo subalterno manifesta-se através das iniciativas e movimentos que constituem a globalização contra-hegemónica. Consiste num vasto conjunto de redes, iniciativas, organizações e movimentos que lutam contra a exclusão económica, social, política e cultural gerada pela mais recente incarnação do capitalismo

\footnotetext{
${ }^{42}$ Não me ocupo aqui dos debates actuais sobre o cosmopolitismo. Na sua longa história, cosmopolitismo significou universalismo, tolerância, patriotismo, cidadania global, comunidade global de seres humanos, culturas globais, etc. O que ocorre mais frequentemente quando este conceito é aplicado - seja como instrumento específico para descrever uma realidade ou como instrumento em lutas políticas - é que a incondicional natureza inclusiva da sua formulação abstracta tem vindo a ser utilizada para prosseguir interesses excludentes de um grupo social específico. De certo modo, o cosmopolitismo tem sido privilégio daqueles que podem tê-lo. A forma como revisito este conceito prevê a identificação dos grupos cujas aspirações são negadas ou tornadas invisíveis pelo uso hegemónico do conceito, mas que podem ser beneficiados pelo uso alternativo do mesmo. Parafraseando Stuart Hall, que levantou uma questão semelhante em relação ao conceito de identidade (1996), eu pergunto: quem precisa do cosmopolitismo? A resposta é simples: todo aquele que for vítima de intolerância e discriminação necessita de tolerância; todo aquele a quem seja negada a dignidade humana básica necessita de uma comunidade de seres humanos; todo aquele que seja não-cidadão necessita da cidadania mundana numa dada comunidade ou nação. Em suma, os socialmente excluídos, vítimas da concepção hegemónica de cosmopolitismo, necessitam de um tipo diverso de cosmopolitismo. O cosmopolitismo subalterno constitui, deste modo, uma variante de oposição. Da mesma forma que a globalização neoliberal não reconhece quaisquer formas alternativas de globalização, também o cosmopolitismo sem adjectivos nega a sua própria especificidade. O cosmopolitismo subalterno de oposição é uma forma cultural e política de globalização contra-hegemónica. É o nome dos projectos emancipatórios cujas reivindicações e critérios de inclusão social vão além dos horizontes do capitalismo global. Outros, com preocupações similares, também adjectivaram o cosmopolitismo: cosmopolitismo enraizado (Cohen, 1992), cosmopolitismo patriótico (Appiah, 1998), cosmopolitismo vernáculo (Bhabha, 1996; Diouf, 2000), etnicidade cosmopolita (Werbner, 2002), ou cosmopolitismo das classes trabalhadoras (Wrebner, 1999). Sobre formas distintas de cosmopolitismo, ver Breckeridge et al. (org.), 2002.
} 
global, conhecido como globalização neoliberal (Santos, 2001, 2006b, 2006c). Atendendo a que a exclusão social é sempre produto de relações de poder desiguais, estas iniciativas, movimentos e lutas são animados por um ethos redistributivo no sentido mais amplo da expressão, o qual implica a redistribuição de recursos materiais, sociais, políticos, culturais e simbólicos e, como tal, se baseia, simultaneamente, no princípio da igualdade e no princípio do reconhecimento da diferença. Desde o início do novo século, o Fórum Social Mundial tem sido a expressão mais conseguida de globalização contra-hegemónica e de cosmopolitismo subalterno. ${ }^{43}$ De entre os movimentos que têm vindo a participar no Fórum Social Mundial, os movimentos indígenas são, do meu ponto de vista, aqueles cujas concepções e práticas representam a mais convincente emergência do pensamento pós-abissal. Este facto é muito auspicioso para a possibilidade de um pensamento pós-abissal, sendo que os povos indígenas são os habitantes paradigmáticos do outro lado da linha, o campo histórico do paradigma da apropriação/violência.

A novidade do cosmopolitismo subalterno reside, acima de tudo, em ter um profundo sentido de incompletude, sem contudo ambicionar a completude. Por um lado, defende que a compreensão do mundo excede largamente a compreensão ocidental do mundo e, portanto, a nossa compreensão da globalização é muito menos global que a própria globalização. Por outro lado, defende que quanto mais compreensões não-ocidentais forem identificadas mais evidente se tornará o facto de que muitas outras continuam por identificar e que as compreensões híbridas, que misturam componentes ocidentais e não-ocidentais, são virtualmente infinitas. $O$ pensamento pós-abissal parte da ideia de que a diversidade do mundo é inesgotável e que esta diversidade continua desprovida de uma epistemologia adequada. Por outras palavras, a diversidade epistemológica do mundo continua por construir.

A seguir apresento um esquema geral do pensamento pós-abissal. Concentro-me nas suas dimensões epistemológicas, deixando de lado as suas dimensões jurídicas. ${ }^{44}$

\section{Pensamento pós-abissal como um pensamento ecológico}

O pensamento pós-abissal parte do reconhecimento de que a exclusão social no seu sentido mais amplo toma diferentes formas conforme é determinada

${ }_{43}$ Sobre a dimensão cosmopolita do Fórum Social Mundial, ver Nisula e Sehm-Patomäki, 2002; Fisher e Ponniah, 2003; Sen et al., 2004; Polet, 2004; Santos, 2006c; Teivainen, no prelo.

${ }^{44}$ Sobre o meu anterior confronto crítico com a epistemologia moderna, ver Santos, 1988, 1995:

7-55, 2000: 209-235, 2004; Santos (org.), 2003a. Ver também Santos, Meneses e Nunes, 2004. 
por uma linha abissal ou não-abissal, e que, enquanto a exclusão abissalmente definida persistir, não será possível qualquer alternativa pós-capitalista progressista. Durante um período de transição possivelmente longo, defrontar a exclusão abissal será um pré-requisito para abordar de forma eficiente as muitas formas de exclusão não-abissal que têm dividido o mundo moderno deste lado da linha. Uma concepção pós-abissal de marxismo (em si mesmo, um bom exemplo de pensamento abissal) pretende que a emancipação dos trabalhadores seja conquistada em conjunto com a emancipação de todas as populações descartáveis do Sul global, que são oprimidas mas não directamente exploradas pelo capitalismo global. Da mesma forma, reivindica que os direitos dos cidadãos não estarão seguros enquanto os não-cidadãos sofrerem um tratamento sub-humano. ${ }^{45}$

O reconhecimento da persistência do pensamento abissal é, assim, a conditio sine qua non para começar a pensar e a agir para além dele. Sem este reconhecimento, o pensamento crítico permanecerá um pensamento derivativo que continuará a reproduzir as linhas abissais, por mais anti-abissal que se autoproclame. Pelo contrário, o pensamento pós-abissal é um pensamento não-derivativo, envolve uma ruptura radical com as formas ocidentais modernas de pensamento e acção. No nosso tempo, pensar em termos não-derivativos significa pensar a partir da perspectiva do outro lado da linha, precisamente por o outro lado da linha ser o domínio do impensável na modernidade ocidental. A emergência do ordenamento da apropriação/violência só poderá ser enfrentada se situarmos a nossa perspectiva epistemológica na experiência social do outro lado da linha, isto é, do Sul global não-imperial, concebido como a metáfora do sofrimento humano sistémico e injusto provocado pelo capitalismo global e pelo colonialismo (Santos, 1995: 506-519). O pensamento pós-abissal pode ser sumariado como um aprender com o Sul usando uma epistemologia do Sul. Confronta a monocultura da ciência moderna com uma ecologia de saberes $^{46}$. É uma ecologia, porque se baseia no reconhecimento da pluralidade de conhecimentos heterogéneos (sendo um deles a ciência moderna)

\footnotetext{
${ }^{45}$ Gandhi é, provavelmente, o pensador-activista dos tempos modernos que mais consistentemente pensou e actuou em termos não-abissais. Tendo vivido e experienciado as exclusões radicais típicas do pensamento abissal, Gandhi não se desviou do seu propósito de construir uma nova forma de universalidade capaz de libertar tanto o opressor como a vítima. Como Ashis Nandy reafirma correctamente: "A visão gandhiana desafia a tentação de igualar o opressor na violência e de readquirir uma auto-estima própria como competidor num mesmo sistema. É uma visão assente numa identificação com os oprimidos que exclui a fantasia da superioridade do estilo de vida do opressor, tão profundamente enraizada na consciência daqueles que reclamam falar em nome das vítimas da história" (1987: 35).

${ }^{46}$ Sobre a ecologia de saberes ver Santos, 2006b: 127-153.
} 
e em interacções sustentáveis e dinâmicas entre eles sem comprometer a sua autonomia. A ecologia de saberes baseia-se na ideia de que o conhecimento é interconhecimento.

\section{Pensamento pós-abissal e co-presença}

A primeira condição para um pensamento pós-abissal é a co-presença radical. A co-presença radical significa que práticas e agentes de ambos os lados da linha são contemporâneos em termos igualitários. A co-presença radical implica conceber simultaneidade como contemporaneidade, o que só pode ser conseguido abandonando a concepção linear de tempo. ${ }^{47}$ Só assim será possível ir além de Hegel (1970), para quem ser membro da humanidade histórica - isto é, estar deste lado da linha - significava ser um grego e não um bárbaro no século $\mathrm{V}$ a.C., um cidadão romano e não um grego nos primeiros séculos da nossa era, um cristão e não um judeu na Idade Média, um europeu e não um selvagem do Novo Mundo no século XVI, e, no século XIX, um europeu (incluindo os europeus deslocados da América do Norte) e não um asiático, parado na história, ou um africano que nem sequer faz parte dela. Além disso, a co-presença radical pressupõe ainda a abolição da guerra, que, juntamente com a intolerância, constitui a negação mais radical da co-presença.

\section{A ecologia de saberes e a inesgotável diversidade da experiência do mundo}

Como ecologia de saberes, o pensamento pós-abissal tem como premissa a ideia da diversidade epistemológica do mundo, o reconhecimento da existência de uma pluralidade de formas de conhecimento além do conhecimento científico. ${ }^{48}$ Isto implica renunciar a qualquer epistemologia geral.

\footnotetext{
${ }^{47}$ Se, hipoteticamente, um camponês africano e um funcionário do Banco Mundial no decurso de uma rápida incursão rural se encontrassem num campo africano, de acordo com o pensamento abissal, o encontro seria simultâneo (o pleonasmo é intencional), mas eles seriam não-contemporâneos; pelo contrário, de acordo com o pensamento pós-abissal, o encontro é simultâneo e tem lugar entre dois indivíduos contemporâneos.

${ }^{48}$ Este reconhecimento da diversidade e diferenciação é um dos componentes fundamentais da Weltanschauung através da qual podemos imaginar o século XXI. Esta Weltanschauung é radicalmente diferente da adoptada pelos países centrais no início do século passado. A imaginação epistemológica no princípio do século XX estava dominada pela ideia de unidade. Este foi o contexto cultural que influenciou as opções teóricas de A. Einstein (Holton, 1998). A premissa da unidade do mundo e a explicação fornecida por esta presidiu a todas as assunções nas quais Einstein baseou a sua pesquisa - simplicidade, simetria, causalidade newtoniana, completude, continuum e explica parcialmente a sua recusa em aceitar a mecânica quântica. Segundo Holton, a ideia da unidade prevaleceu no contexto cultural do tempo, especialmente na Alemanha. Trata-se de uma ideia que atingira a expressão mais brilhante no conceito de Goethe de unidade orgânica da humanidade e da natureza e da completa articulação de todos os elementos da natureza. Foi esta mesma ideia que, em 1912, conduziu cientistas e filósofos à produção de um manifesto para a criação de uma nova sociedade que visava desenvolver um conjunto de ideias unificadoras e conceitos unificadores a aplicar a todos os campos do saber (Holton, 1998: 26).
} 
Em todo o mundo, não só existem diversas formas de conhecimento da matéria, sociedade, vida e espírito, como também muitos e diversos conceitos sobre o que conta como conhecimento e os critérios que podem ser usados para validá-lo. No período de transição que iniciamos, no qual resistem ainda as versões abissais de totalidade e unidade, provavelmente precisamos, para seguir em frente, de uma epistemologia geral residual ou negativa: uma epistemologia geral da impossibilidade de uma epistemologia geral.

\section{Saberes e ignorâncias}

O contexto cultural em que se situa a ecologia de saberes é ambíguo. Por um lado, a ideia da diversidade sociocultural do mundo que tem ganhado fôlego nas três últimas décadas e favorece o reconhecimento da diversidade e pluralidade epistemológica como uma das suas dimensões. Por outro lado, se todas as epistemologias partilham as premissas culturais do seu tempo, talvez uma das mais bem consolidadas premissas do pensamento abissal seja, ainda hoje, a da crença na ciência como única forma de conhecimento válido e rigoroso. Ortega y Gasset (1942) propôs uma distinção radical entre crenças e ideias, entendendo por estas últimas a ciência ou a filosofia. A distinção reside em que as crenças são parte integrante da nossa identidade e subjectividade, enquanto as ideias são algo que nos é exterior. Enquanto as nossas ideias nascem da dúvida e permanecem nela, as nossas crenças nascem da ausência dela. No fundo, a distinção é entre ser e ter: somos as nossas crenças, temos ideias. O que é característico do nosso tempo é o facto de a ciência moderna pertencer simultaneamente ao campo das ideias e ao campo das crenças. A crença na ciência excede em muito o que as ideias científicas nos permitem realizar. Assim, a relativa perda de confiança epistemológica na ciência, que percorreu toda a segunda metade do século XX, ocorreu de par com a crescente crença popular na ciência. A relação entre crenças e ideias deixa de ser uma relação entre duas entidades distintas para passar a ser uma relação entre duas formas de experienciar socialmente a ciência. Esta dualidade faz com que o reconhecimento da diversidade cultural do mundo não signifique necessariamente o reconhecimento da diversidade epistemológica do mundo.

Neste contexto, a ecologia de saberes é, basicamente, uma contra-epistemologia. O impulso básico que a faz emergir resulta de dois factores. O primeiro é o novo surgimento político de povos e visões do mundo do outro lado da linha como parceiros da resistência ao capitalismo global, isto é, a globalização contra-hegemónica. Em termos geopolíticos, trata-se de sociedades periféricas do sistema mundial moderno onde a crença na ciên- 
cia moderna é mais ténue, onde é mais visível a vinculação da ciência moderna aos desígnios da dominação colonial e imperial, e onde outros conhecimentos não-científicos e não-ocidentais prevalecem nas práticas quotidianas das populações. O segundo factor é uma proliferação sem precedentes de alternativas que, contudo, não podem ser agrupadas sob a alçada de uma única alternativa global. A globalização contra-hegemónica destaca-se pela ausência de uma tal alternativa no singular. A ecologia de saberes procura dar consistência epistemológica ao pensamento pluralista e propositivo.

$\mathrm{Na}$ ecologia de saberes cruzam-se conhecimentos e, portanto, também ignorâncias. Não existe uma unidade de conhecimento, como não existe uma unidade de ignorância. As formas de ignorância são tão heterogéneas e interdependentes quanto as formas de conhecimento. Dada esta interdependência, a aprendizagem de certos conhecimentos pode envolver o esquecimento de outros e, em última instância, a ignorância destes. Por outras palavras, na ecologia de saberes, a ignorância não é necessariamente um estado original ou ponto de partida. Pode ser um ponto de chegada. Pode ser o resultado do esquecimento ou desaprendizagem implícitos num processo de aprendizagem recíproca. Assim, num processo de aprendizagem conduzido por uma ecologia de saberes, é crucial a comparação entre o conhecimento que está a ser aprendido e o conhecimento que nesse processo é esquecido e desaprendido. A ignorância só é uma forma desqualificada de ser e de fazer quando o que se aprende vale mais do que o que se esquece. A utopia do interconhecimento é aprender outros conhecimentos sem esquecer os próprios. É esta a tecnologia de prudência que subjaz à ecologia de saberes. Ela convida a uma reflexão mais profunda sobre a diferença entre a ciência como conhecimento monopolista e a ciência como parte de uma ecologia de saberes.

\section{A ciência moderna como parte de uma ecologia de saberes}

Como produto do pensamento abissal, o conhecimento científico não se encontra distribuído socialmente de forma equitativa, nem poderia encontrar-se, uma vez que o seu desígnio original foi a conversão deste lado da linha em sujeito do conhecimento e do outro lado da linha em objecto de conhecimento. As intervenções no mundo real que favorece tendem a ser as que servem os grupos sociais que têm maior acesso a este conhecimento. Enquanto as linhas abissais continuarem a desenhar-se, a luta por uma justiça cognitiva não terá sucesso se se basear apenas na ideia de uma distribuição mais equitativa do conhecimento científico. Para além do facto de tal distribuição ser impossível nas condições do capitalismo e colonia- 
lismo, o conhecimento científico tem limites intrínsecos em relação ao tipo de intervenção que promove no mundo real. $\mathrm{Na}$ ecologia de saberes, enquanto epistemologia pós-abissal, a busca de credibilidade para os conhecimentos não-científicos não implica o descrédito do conhecimento científico. Implica, simplesmente, a sua utilização contra-hegemónica. Trata-se, por um lado, de explorar a pluralidade interna da ciência, isto é, as práticas científicas alternativas que se têm tornado visíveis através das epistemologias feministas ${ }^{49}$ e pós-coloniais ${ }^{50}$ e, por outro lado, de promover a interacção e a interdependência entre os saberes científicos e outros saberes, não-científicos.

Uma das premissas básicas da ecologia de saberes é que todos os conhecimentos têm limites internos e limites externos. Os internos dizem respeito aos limites das intervenções no real que permitem. Os externos decorrem do reconhecimento de intervenções alternativas tornadas possíveis por outras formas de conhecimento. Por definição, as formas de conhecimento hegemónico só conhecem os limites internos, portanto, o uso contra-hegemónico da ciência moderna só é possível através da exploração paralela dos seus limites internos e externos como parte de uma concepção contra hegemónica de ciência. É por isso que o uso contra-hegemónico da ciência não pode limitar-se à ciência. Só faz sentido no âmbito de uma ecologia de saberes.

Para uma ecologia de saberes, o conhecimento como intervenção no real - não o conhecimento como representação do real - é a medida do realismo. A credibilidade da construção cognitiva mede-se pelo tipo de intervenção no mundo que proporciona, ajuda ou impede. Como a avaliação dessa intervenção combina sempre o cognitivo com o ético-político, a ecologia de saberes distingue a objectividade analítica da neutralidade ético-política. Ninguém questiona hoje o valor geral das intervenções no real tornadas possíveis pela ciência moderna através da sua produtividade tecnológica. Mas este facto não deve impedir-nos de reconhecer outras intervenções no real tornadas possíveis por outras formas de conhecimento. Em muitas áreas da vida social, a ciência moderna tem demonstrado uma superioridade indiscutível em relação a outras formas de conhecimento. Existem, no

\footnotetext{
${ }^{49}$ As epistemologias feministas têm sido centrais para a crítica dos dualismos "clássicos" da modernidade, como sejam natureza/cultura, sujeito/objecto, humano/não-humano, e da naturalização das hierarquias de classe, sexo e raça. Para alguns contributos relevantes para as críticas feministas da ciência, ver Keller, 1985; Harding, 1986, 1998, 2003; Schiebinger, 1989, 1999; Haraway, 1992, 1997; Soper, 1995; Fausto-Sterling, 2000; Gardey e Lowy, 2000. Creager, Lunbeck, e Schiebinger, 2001, oferece uma panorâmica interessante, ainda que centrada no Norte global.

${ }^{50}$ Entre muitos outros, ver Alvares, 1992; Dussel, 1995; Santos, 1995; Santos (org.), 2003a e 2004a; Guha e Martinez-Alier, 1997; Visvanathan, 1997; Ela, 1998; Prakash, 1999; Quijano, 2000; Mignolo, 2000; Mbembe, 2001; e Masolo, 2003.
} 
entanto, outras formas de intervenção no real que hoje nos são valiosas e para as quais a ciência moderna nada contribuiu. É o caso, por exemplo, da preservação da biodiversidade tornada possível por formas de conhecimento camponesas e indígenas e que, paradoxalmente, se encontram hoje ameaçadas pela intervenção crescente da ciência moderna (Santos, Meneses e Nunes, 2004). E não deverá espantar-nos a riqueza dos conhecimentos que conseguiram preservar modos de vida, universos simbólicos e informações vitais para a sobrevivência em ambientes hostis com base exclusivamente na tradição oral? Dirá algo sobre a ciência o facto de que através dela tal nunca teria sido possível?

Aqui reside o impulso para a co-presença igualitária (como simultaneidade e contemporaneidade), e para a incompletude. Uma vez que nenhuma forma singular de conhecimento pode responder por todas as intervenções possíveis no mundo, todas elas são, de diferentes maneiras, incompletas. A incompletude não pode ser erradicada porque qualquer descrição completa das variedades de saber não incluiria a forma de saber responsável pela própria descrição. Não há conhecimento que não seja conhecido por alguém para alguns objectivos. Todos os conhecimentos sustentam práticas e constituem sujeitos. Todos os conhecimentos são testemunhais porque o que conhecem sobre o real (a sua dimensão activa) se reflecte sempre no que dão a conhecer sobre o sujeito do conhecimento (a sua dimensão subjectiva). Ao questionarem a distinção sujeito/objecto, as ciências da complexidade dão conta deste fenómeno, mas confinam-no às práticas científicas. A ecologia de saberes expande o carácter testemunhal dos conhecimentos de forma a abarcar igualmente as relações entre o conhecimento científico e não-científico, alargando deste modo o alcance da inter-subjectividade como interconhecimento e vice-versa.

Num regime de ecologia de saberes, a busca de inter-subjectividade é tão importante quanto complexa. Dado que diferentes práticas de conhecimento têm lugar em diferentes escalas espaciais e de acordo com diferentes durações e ritmos, a inter-subjectividade requer também a disposição para conhecer e agir em escalas diferentes (inter-escalaridade) e articulando diferentes durações (inter-temporalidade). Muitas das experiências subalternas de resistência são locais ou foram localizadas e assim tornadas irrelevantes ou inexistentes pelo conhecimento abissal moderno, o único capaz de gerar experiências globais. Contudo, uma vez que a resistência contra as linhas abissais tem de ter lugar a uma escala global, é imperativo desenvolver algum tipo de articulação entre as experiências subalternas através de ligações locais-globais. Para ser bem sucedida, a ecologia de saberes tem de ser trans-escalar (Santos, 2000: 209-235). 
Além disso, a coexistência de diferentes temporalidades ou durações em diferentes práticas de conhecimento requer uma expansão da moldura temporal. Enquanto as modernas tecnologias tendem a favorecer a moldura temporal e a duração da acção estatal, tanto na administração pública como na política (o ciclo eleitoral, por exemplo), as experiências subalternas do Sul global têm sido forçadas a responder tanto à curta duração das necessidades imediatas de sobrevivência como à longa duração do capitalismo e do colonialismo. Mesmo nas lutas subalternas podem estar presentes diferentes durações. Como exemplo, a luta pela terra dos camponeses empobrecidos da América Latina pode incluir a duração do Estado moderno, quando, por exemplo, no Brasil, o Movimento dos Sem Terra (MST) luta pela reforma agrária, a duração da escravatura, quando os povos afro-descendentes lutam pela recuperação dos Quilombos, a terra dos escravos fugitivos, seus antepassados, ou ainda a duração ainda mais longa, do colonialismo, quando os povos indígenas lutam para reaver os seus territórios históricos de que foram esbulhados pelos conquistadores.

\section{Ecologia de saberes, hierarquia e pragmática}

A ecologia de saberes não concebe os conhecimentos em abstracto, mas antes como práticas de conhecimento que possibilitam ou impedem certas intervenções no mundo real. Um pragmatismo epistemológico é, acima de tudo, justificado pelo facto de as experiências de vida dos oprimidos lhes serem inteligíveis por via de uma epistemologia das consequências. No mundo em que vivem, as consequências vêm sempre primeiro que as causas.

A ecologia de saberes assenta na ideia pragmática de que é necessária uma reavaliação das intervenções e relações concretas na sociedade e na natureza que os diferentes conhecimentos proporcionam. Centra-se, pois, nas relações entre saberes, nas hierarquias que se geram entre eles, uma vez que nenhuma prática concreta seria possível sem estas hierarquias. Contudo, em lugar de subscrever uma hierarquia única, universal e abstracta entre os saberes, a ecologia de saberes favorece hierarquias dependentes do contexto, à luz dos resultados concretos pretendidos ou atingidos pelas diferentes formas de saber. Hierarquias concretas emergem do valor relativo de intervenções alternativas no mundo real. Entre os diferentes tipos de intervenção pode existir complementaridade ou contradição. ${ }^{51}$ Sempre que há intervenções no real que podem, em teoria, ser levadas a cabo por diferentes sistemas

\footnotetext{
${ }^{51}$ A prevalência dos juízos cognitivos ao levar a cabo uma determinada prática de conhecimento não choca com a prevalência dos juízos ético-políticos na decisão a favor de um determinado tipo de intervenção real que esse conhecimento específico possibilita em detrimento de intervenções alternativas possibilitadas por conhecimentos alternativos.
} 
de conhecimento, as escolhas concretas das formas de conhecimento a privilegiar devem ser informadas pelo princípio de precaução, que, no contexto da ecologia de saberes, deve formular-se assim: deve dar-se preferência às formas de conhecimento que garantam a maior participação dos grupos sociais envolvidos na concepção, na execução, no controlo e na fruição da intervenção.

O exemplo seguinte ilustra bem os perigos de substituir um tipo de conhecimento por outro com base em hierarquias abstractas. Nos anos de 1960, os sistemas milenares de irrigação dos campos de arroz da ilha de Bali, na Indonésia, foram substituídos por sistemas científicos de irrigação, promovidos pelos prosélitos da revolução verde. Os sistemas tradicionais de irrigação assentavam em conhecimentos hidrológicos, agrícolas e religiosos ancestrais, e eram administrados por sacerdotes de um templo hindu-budista dedicado a Dewi-Danu, a deusa do lago. Foram substituídos precisamente por serem considerados produtos da magia e da superstição, derivados do que foi depreciativamente designado como "culto do arroz". Acontece que a substituição teve resultados desastrosos para a cultura do arroz com decréscimos nas colheitas para mais de metade. Os maus resultados repetiram-se nas colheitas seguintes e foram tão desastrosos que os sistemas científicos tiveram de ser abandonados e os sistemas tradicionais repostos (Lansing, 1987, 1991; Lansing e Kremer, 1993). Este caso ilustra a importância do princípio da precaução quando lidamos com uma possível complementaridade ou contradição entre diferentes tipos de conhecimento. É que, além do mais, a suposta incompatibilidade entre dois sistemas de conhecimento (o religioso e o científico) para a realização da mesma intervenção (a irrigação dos campos de arroz) foi o resultado de uma má avaliação (má ciência) provocada precisamente por juízos abstractos baseados na superioridade abstracta do conhecimento científico. Trinta anos depois da desastrosa intervenção técnico-científica, a modelação computacional - uma área das novas ciências ou ciências da complexidade - veio demonstrar que as sequências da água geridas pelos sacerdotes da deusa Dewi-Danu eram os mais eficientes possíveis, mais eficientes, portanto, do que as do sistema científico de irrigação ou qualquer outro (Lansing e Kremer, 1993).

\section{Ecologia de saberes, incomensurabilidade e tradução}

$\mathrm{Na}$ perspectiva das epistemologias abissais do Norte global, o policiamento das fronteiras do conhecimento relevante é de longe mais decisivo do que as discussões sobre diferenças internas. Como consequência, um epistemicídio maciço tem vindo a decorrer nos últimos cinco séculos, e uma riqueza imensa de experiências cognitivas tem vindo a ser desperdiçada. Para recu- 
perar algumas destas experiências, a ecologia de saberes recorre ao seu atributo pós-abissal mais característico, a tradução intercultural. Embebidas em diferentes culturas ocidentais e não-ocidentais, estas experiências não só usam linguagens diferentes, mas também distintas categorias, diferentes universos simbólicos e aspirações a uma vida melhor.

As profundas diferenças entre saberes levantam a questão da incomensurabilidade, uma questão utilizada pela epistemologia abissal para desacreditar a mera possibilidade de um ecologia de saberes. Um exemplo ajuda a ilustrar esta questão. Será possível estabelecer um diálogo entre a filosofia ocidental e a filosofia africana? Formulada assim, a pergunta parece só permitir uma resposta positiva, uma vez que elas partilham algo em comum: são ambas filosofia..$^{52}$ No entanto, para muitos filósofos ocidentais e africanos, não é possível referirmo-nos a uma filosofia africana porque existe apenas uma filosofia, cuja universalidade não é posta em causa pelo facto de até ao momento se ter desenvolvido sobretudo no Ocidente. Em África, esta é a posição dos chamados filósofos modernistas. Para outros filósofos africanos, os filósofos tradicionalistas, há filosofia africana mas, como ela está embebida na cultura africana, é incomensurável com a filosofia ocidental e deve seguir o seu desenvolvimento autónomo. ${ }^{53}$ Entre estas duas posições, há aquelas que defendem que existem muitas filosofias e que é possível o diálogo entre elas e o enriquecimento mútuo. Estas posições vêem-se frequentemente confrontadas com os problemas da incomensurabilidade, incompatibilidade e ininteligibilidade recíprocas que procuram resolver, explorando formas, por vezes insuspeitadas, de complementaridade. Tudo depende do uso de procedimentos adequados de tradução intercultural. Através da tradução, torna-se possível identificar preocupações comuns, aproximações complementares e, claro, também contradições inultrapassáveis. ${ }^{54}$

Um exemplo ilustra o que está em jogo. O filósofo ganiano Kwasi Wiredu afirma que na cultura e língua Akan, do Gana (grupo étnico a que pertence) não é possível traduzir o preceito cartesiano "cogito ergo sum" $(1990,1996)$. A razão é que não há palavras para exprimir tal ideia. "Pensar", em Akan, significa "medir algo", o que não faz sentido quando acoplado à ideia de

\footnotetext{
${ }_{52} \mathrm{O}$ mesmo argumento pode ser usado em relação a um diálogo entre religiões.

53 Sobre este assunto, ver Eze, 1997; Karp e Masolo, 2000; Hountondji, 2002; Coetzee and Roux, 2002; Brown, 2004.

${ }^{54}$ Nesta área, os problemas estão frequentemente associados com a linguagem, e esta é, de facto, um instrumento chave para o desenvolvimento de uma ecologia dos saberes. Como resultado, a tradução deve operar a dois níveis, o linguístico e o cultural. A tradução cultural será uma das tarefas mais desafiantes que se apresenta a filósofos, cientistas sociais e activistas no século XXI. Trato deste assunto com maior detalhe em Santos, 2004 e 2006b.
} 
ser. Mais ainda, o "ser" de "sum" é igualmente muito difícil de exprimir porque o equivalente mais próximo é algo semelhante a "estou aí". Segundo Wiredu, o locativo "ấ" "seria suicida tanto do ponto de vista da epistemologia como da metafísica do cogito". Ou seja, a língua permite exprimir certas ideias e não outras. Isto não significa, contudo, que a relação entre a filosofia africana e a filosofia ocidental tenha de ficar por aqui. Como Wiredu tenta demonstrar, é possível desenvolver argumentos autónomos com base na filosofia africana, não só sobre o porquê de esta não poder exprimir o "cogito ergo sum", mas também sobre as muitas ideias alternativas que ela pode exprimir e que a filosofia ocidental não pode. ${ }^{55}$

\section{Ecologia de saberes, mythos, e clinamen}

A ecologia de saberes não ocorre apenas no plano do logos. Ocorre também no do mythos. A ideia de emergência ou o "Ainda Não" de Ernst Bloch é aqui essencial (Bloch, 1995: 241). ${ }^{56} \mathrm{~A}$ intensificação da vontade resulta de uma leitura potenciadora de tendências objectivas, que emprestam força a uma possibilidade auspiciosa, mas frágil, decorrente de uma compreensão mais profunda das possibilidades humanas com base nos saberes que, ao contrário do científico, privilegiam a força interior em vez da força exterior, a natura naturans em vez da natura naturata. ${ }^{57}$ Através destes saberes é possível alimentar o valor intensificado de um empenhamento, o que é incompreensível do ponto de vista do mecanicismo positivista e funcionalista da ciência moderna.

Deste empenho surgirá uma capacidade nova de inquirição e indignação, capaz de fundamentar teorias e práticas novas, umas e outras inconformistas, destabilizadoras e mesmo rebeldes. O que está em jogo é a criação de uma previsão activa baseada na riqueza da diversidade não-canónica do mundo e de um grau de espontaneidade baseado na recusa de deduzir o potencial do factual. Desta forma, os poderes constituídos deixam de ser destino podendo ser realisticamente confrontados com os poderes constituintes. O que importa, pois, é desfamiliarizar a tradição canónica das monoculturas do saber sem parar aí, como se essa desfamiliarização fosse a única familiaridade possível.

\footnotetext{
55 Sobre este assunto e o debate que ele suscita, ver Wiredu, 1997, e a discussão do seu trabalho em Osha, 1999.

56 Sobre a sociologia das emergências, ver Santos, 2004 e 2006b: 87-126.

57 De uma perspectiva distinta, a ecologia dos saberes procura a mesma complementaridade que, no Renascimento, Paracelso (1493-1541) identificou entre "Archeus", a vontade elementar na semente e no corpo, e "Vulcanus", a força natural da matéria. Ver Paracelso, 1989: 33 e todo o texto sobre "microcosmos e macrocosmos" (1989: 17-67). Ver também Paracelso,1967.
} 
A ecologia de saberes é uma epistemologia destabilizadora no sentido em que se empenha numa crítica radical da política do possível, sem ceder a uma política impossível. Central a uma ecologia de saberes não é a distinção entre estrutura e acção, mas antes a distinção entre acção conformista e aquilo que designo por acção-com-clinamen.$^{58} \mathrm{~A}$ acção conformista é uma prática rotineira, reprodutiva e repetitiva que reduz o realismo àquilo que existe e apenas porque existe. Para a minha noção de acção-com-clinamen, tomo de Epicuro e Lucrécio o conceito de clinamen, entendido como o "quiddam" inexplicável que perturba a relação entre causa e efeito, ou seja, a capacidade de desvio que Epicuro atribuiu aos átomos de Demócrito. O clinamen é o que faz com que os átomos deixem de parecer inertes e revelem um poder de inclinação, isto é, um poder de movimento espontâneo (Epicurus, 1926; Lucretius, 1950).59 Ao contrário do que acontece na acção revolucionária, a criatividade da acção-com-clinamen não assenta numa ruptura dramática, antes num ligeiro desvio, cujos efeitos cumulativos tornam possíveis as combinações complexas e criativas entre átomos, assim como entre seres vivos e grupos sociais. ${ }^{60} \mathrm{O}$ clinamen não recusa $\mathrm{o}$ passado; pelo contrário, assume-o e redime-o pela forma como dele se desvia. O seu potencial para o pensamento pós-abissal decorre da sua capacidade para atravessar as linhas abissais. A ocorrência de acção-com-clinamen é em si mesma inexplicável. O papel de uma ecologia de saberes a este respeito será somente o de identificar as condições que maximizam a probabilidade de uma tal ocorrência e definir, ao mesmo tempo, o horizonte de possibilidades em que o desvio virá a "operar". A ecologia de saberes é constituída por sujeitos desestabilizadores, individuais ou colectivos, e é, ao mesmo tempo, constitutiva deles. A subjectividade capaz da ecologia dos saberes é uma subjectividade dotada de uma especial capacidade, energia e vontade para agir com clinamen. A própria construção social de uma tal subjectividade implica necessariamente recorrer a formas excêntricas ou marginais de sociabilidade ou subjectividade dentro ou fora da modernidade ocidental, as formas que recusaram a ser definidas de acordo com os critérios abissais.

\footnotetext{
${ }_{58}$ Desenvolvo este conceito em Santos, 1998.

$59 \mathrm{O}$ conceito de clinamen entrou na teoria literária pela mão Harold Bloom. É uma das rationes revisionistas da sua teoria da influência poética. Em The Anxiety of Influence, Bloom serve-se da noção de clinamen para explicar a criatividade poética como uma tresleitura que é antes trans-leitura (o termo bloomiano é misreading, um ler-mal que é também ler-mais-do-que-bem, ou corrigir). Diz Bloom: "Um poeta desvia-se do poema do seu precursor, executando um clinamen em relação a ele” (Bloom, 1973: 14).

${ }^{60}$ Como diz Lucrécio, o desvio é per paucum nec plus quam minimum (Epicurus, 1926: introdução de Frederic Manning, XXXIV).
} 


\section{Conclusão}

A construção epistemológica de uma ecologia de saberes não é tarefa fácil. Como conclusão, proponho um programa de pesquisa. Podemos identificar três conjuntos principais de questões, relacionados com a identificação de saberes, com os procedimentos que permitem relacioná-los entre si e com a natureza e avaliação das intervenções no mundo real que possibilitam. O primeiro questionamento levanta uma série de questões que têm sido ignoradas pelas epistemologias do Norte global. Qual a perspectiva partir da qual poderemos identificar diferentes conhecimentos? Como podemos distinguir o conhecimento científico do conhecimento não-científico? Como distinguir entre os vários conhecimentos não-científicos? Como se distingue o conhecimento não-ocidental do conhecimento ocidental? Se existem vários conhecimentos ocidentais e vários conhecimentos não-ocidentais, como distingui-los entre si? Qual a configuração dos conhecimentos híbridos que agregam componentes ocidentais e não-ocidentais?

A segunda área de questionamento levanta as seguintes questões. Que tipos de relacionamento são possíveis entre os diferentes conhecimentos? Como distinguir incomensurabilidade, contradição, incompatibilidade, e complementariedade? Donde provém a vontade de traduzir? Quem são os tradutores? Como escolher os parceiros e tópicos de tradução? Como formar decisões partilhadas e distingui-las das impostas? Como assegurar que a tradução intercultural não se transforma numa versão renovada do pensamento abissal, numa versão "suavizada" de imperialismo e colonialismo?

O terceiro questionamento diz respeito à natureza e avaliação das intervenções no mundo real. Como podemos traduzir esta perspectiva em práticas de conhecimento? Na busca de alternativas à dominação e à opressão, como distinguir entre alternativas ao sistema de opressão e dominação e alternativas dentro do sistema ou, mais especificamente, como distinguir alternativas ao capitalismo de alternativas dentro do capitalismo?

Em suma, como combater as linhas abissais usando instrumentos conceptuais e políticos que as não reproduzam? E, finalmente, uma questão com especial interesse para educadores: qual seria o impacto de uma concepção pós-abissal de conhecimento (como uma ecologia de saberes) sobre as instituições educativas e centros de investigação? Nenhuma destas perguntas tem respostas definitivas. Mas o esforço para tentar dar-lhes resposta - certamente um esforço colectivo e civilizacional - é, provavelmente, a única forma de confrontar a nova e mais insidiosa versão do pensamento abissal identificada neste trabalho: a constante ascensão do paradigma da apropriação/violência no interior do paradigma da regulação/emancipação. 
É próprio da natureza da ecologia de saberes constituir-se através de perguntas constantes e respostas incompletas. Aí reside a sua característica de conhecimento prudente. A ecologia de saberes capacita-nos para uma visão mais abrangente daquilo que conhecemos, bem como do que desconhecemos, e também nos previne para que aquilo que não sabemos é ignorância nossa, não ignorância em geral.

A vigilância epistemológica requerida pela ecologia de saberes transforma o pensamento pós-abissal num profundo exercício de auto-reflexividade. Requer que os pensadores e actores pós-abissais se vejam num contexto semelhante àquele em que Santo Agostinho se encontrava ao escrever as suas Confissões e que expressou eloquentemente desta forma: quaestio mibi factus sum, "Converti-me numa questão para mim". A diferença é que o tópico deixou de ser a confissão dos erros passados, para ser a participação solidária na construção de um futuro pessoal e colectivo, sem nunca se ter a certeza de não repetir os erros cometidos no passado.

\section{Referências bibliográficas}

Afzal-Khan, F.; Sheshadri-Crooks, K. (2000), The Pre-occupation of Postcolonial Studies. Durham: Duke UP.

Agamben, Giorgio (2004), State of Exception. Chicago: University of Chicago Press. Ahmad, Ibn Majid Al-Najdi (1971), Arab Navigation in the Indian Ocean Before the Coming of the Portuguese: Being a translation of Kitab al-Fawa'id fi usul al-babr wa'lqawa'id of Abmad b. Majid Al-Najdi, together with an introduction on the history of Arab navigation, notes on the navigational techniques and the topography of Indian Ocean, and a glossary of Navigational terms by G. R. Tibbetts. London: Royal Asiatic Society of Great Britain and Ireland.

Akram, Susan Musarrtat (1999), "Scheherezade Meets Kafka: Two Dozen Sordid Tales of Ideological Exclusion”, Georgetown Immigration Law Journal, 14, 51-150.

Akram, Susan Musarrat (2000), "Orientalism Revisited in Asylum and Refugee Claims", International Journal of Refugee Law, 12(1), 7-40.

Akram, Susan M.; Karmely, Maritza (2005), "Immigration and Constitutional Consequences of Post-9/11 Policies involving Arabs and Muslims in the United States: Is Alienage a Distinction without a Difference?", U.C. Davis Law Review, 38(3), 609-699. Alvares, Claude (1992), Science, Development and Violence: The Revolt against Modernity. New Delhi: Oxford UP.

Amann, Diane Marie (2004a), "Guantánamo”, Columbia Journal of Transnational Law, 42(2), 263-348.

Amann, Diane Marie (2004b), "Abu Ghraib”, University of Pennsylvania Law Review, 153(6), 2085-2141. 
Anghie, Anthony (2005), Imperialism, Sovereignty and the Making of International Law. Cambridge: Cambridge UP.

Appiah, Kwame Anthony (1998), "Cosmopolitan Patriots", in P. Cheah; B. Robbins (orgs.), Cosmopolitics: Thinking and Feeling Beyond the Nation. Minneapolis: University of Minnesota Press, 91-116.

Arendt, Hannah (1951), The Origins of Totalitarianism. New York: Harcourt, Brace. Atkinson, Rowland; Blandy, Sarah (2005), "International Perspectives on the New Enclavism and the Rise of Gated Communities", Housing Studies, 20(2), 177-186. Ayres, Ian; Braithwaite, John (1992), Responsive Regulation: Transcending the Deregulation Debate. New York: Oxford UP.

Balanyá, Belén et al. (orgs.) (2005), Reclaiming Public Water: Acbievements, Struggles and Visions from Around the World. Amsterdam: Transnational Institute and Corporate Europe Observatory. Acessível em <http://www.tni.org/books/publicwater. htm>.

Bambirra, Vania (1978), Teoria de la Dependencia: Una anticritica. Ciudad de México: Era.

Barr, Bob (2004), "USA PATRIOT Act and Progeny Threaten the Very Foundation of Freedom”, Georgetown Journal of Law E Public Policy, 2(2), 385-392.

Bauer, Carl J. (1998), Against the Current: Privatization, Water Markets, and the State in Chile. London: Kluwer Academic Publishers.

Bauer, Laura Isabel (2004), “They Beg Our Protection and We Refuse: U.S. Asylum Law's Failure to Protect Many of Today's Refugees”, Notre Dame Law Review, 79(3), 1081-1116.

Bhabha, Homi (1996), "Unsatisfied: Notes on Vernacular Cosmopolitanism”, in L. Garcia-Morena; P. C. Pfeifer (orgs.), Text and Nation. London: Camden House, 191-207.

Blakely, Edward J.; Snyder, Mary Gail (1999), Fortress America: Gated Communities in the United States. Cambridge, MA: Brookings Institution Press.

Bloch, Ernst (1995), The Principle of Hope. Cambridge, MA: MIT Press [1947].

Bloom, Harold (1973), The Anxiety of Influence. Oxford: Oxford UP.

Bond Patrick (2000), Elite Transition: From Apartheid to Neoliberalism in South Africa. London: Pluto Press.

Borelli, Silvia (2005), "Casting Light on the Legal Black Hole: International Law and Detentions Abroad in the "War on Terror", International Review of the Red Cross, 87(857), 39-68.

Boyne, Shawn (2004), "Law, Terrorism, and Social Movements: The Tension between Politics and Security in Germany's Anti-Terrorism Legislation”, Cardozo Journal of International and Comparative Law, 12(1), 41-82.

Breckenridge, Carol et al. (orgs.) (2002), Cosmopolitanism. Durham: Duke UP.

Brown, Lee M. (org.) (2004), African Philosophy: New and Traditional Perspectives. New York: Oxford UP. 
Brown, Michelle (2005), “'Setting the Conditions' for Abu Ghraib: The Prison Nation Abroad”, American Quarterly, 57(3), 973-997.

Buchanan, Patrick J. (2006), State of Emergency: the Third World Invasion and Conquest of America. New York: St. Martin's Press.

Buhlungu, Sakhela et al. (2006), State of the Nation 2005-2006. South Africa: HSRC Press.

Burnett, D. Graham (2002), “'It Is Impossible to Make a Step without the Indians': Nineteenth-Century Geographical Exploration and the Amerindians of British Guiana”, Ethnobistory, 49(1), 3-40.

Cabral, Amílcar (1979), Unity and Struggle: Speeches and Writings of Amílcar Cabral. New York: Monthly Review Press.

Cardoso, Fernando Henrique; Faletto, Enzo (1969), Dependencia y Desarrollo en America Latina. Cidade do México: SigloXXI.

Castro, José Esteban (2006), Water, Power and Citizenship: Social Struggle in the Basin of Mexico. Basingstoke, U.K./New York: Palgrave Macmillan.

Césaire, Aimé (2000), Discourse on Colonialism. New York: N. Y. U. P.

Chew, Sing C.; Denemark, Robert A. (orgs.) (1996), The Underdevelopment of Development: Essays in honor of Andre Gunder Frank. Thousand Oaks, CA: Sage.

Chang, Nancy (2001), “The USA Patriot Act: What's So Patriotic about Trampling on the Bill of Rights", Guild Practitioner, 58(3), 142-158.

Cianciarulo, Marisa Silenzi (2005), "The W Visa: A Legislative Proposal for Female and Child Refugees Trapped in a Post-September 11 World”, Yale Journal of Law and Feminism, 17(2), 459-500.

Cohen, Mitchell (1992), "Rooted Cosmopolitanism: Thoughts on the Left, Nationalism, and Multiculturalism”, Dissent, 39(4), 478-483.

Coetzee, H.; Roux, A. P. J. (orgs.) (2002), Philosophy from Africa: A Text with Readings. Cape City: Oxford UP.

Conca, Ken (2005), Governing Water: Contentious Transnational Politics and Global Institution Building. Cambridge, MA: The MIT Press.

Coy, Martin (2006), "Gated Communities and Urban Fragmentation in Latin America: The Brazilian Experience”, GeoJournal, 66(1-2), 121-132.

Creager, Angela N. H.; Lunbeck, Elizabeth; Schiebinger, Londa (orgs.) (2001), Feminism in the Twentieth-Century: Science, Technology, and Medicine. Chicago: University of Chicago Press.

David, C. W. A. (1924), "The Fugitive Slave Law of 1793 and its Antecedents", The Journal of Negro History, 9(1), 18-25.

De Genova, Nicholas P. (2002), “Migrant 'Illegality' and Deportability in Everyday Life”, Annual Review of Anthropology, 31, 419-447.

Dean, Bartholomew; Levi, Jerome M. (orgs.) (2003), At the Risk of Being Heard: Identity, Indigenous Rights, and Postcolonial States. Ann Arbor: University of Michigan Press. 
Dershowitz, Alan (2002), Why Terrorism Works: Understanding the Threat, Responding to the Challenge. New Haven: Yale UP.

Dershowitz, Alan (2003a), "Reply: Torture without Visibility and Accountability is Worse than with It", University of Pennsylvania Journal of Constitutional Law, 6, 326.

Dershowitz, Alan (2003b), “The Torture Warrant: A Response to Professor Strauss”, New York Law School Law Review, 48, 275-294.

Dickinson, Laura (2005), "Torture and Contract", Case Western Reserve Journal of International Law, 37(5-3), 267-275.

Diouf, Mamadou (2000), "The Senegalese Murid Trade Diaspora and the Making of a Vernacular Cosmopolitanism”, Public Culture, 12(3), 679-702.

Donahue, John; Johnston, Barbara (orgs.) (1998), Water, Culture and Power: Local Struggles in a Global Context. Washington, DC: Island Press.

Dorf, Michael; Sabel, Charles (1998), “A Construction of Democratic Experimentalism”, Columbia Law Review, 98, 267-473.

Dörmann, Knut (2003), “The Legal Situation of Unlawful/Unprivileged Combatants”, International Review of the Red Cross, 85(849), 45-74.

Dos Santos, Theotonio (1971), El Nuevo Carácter de la Dependencia. Buenos Aires: S. Ediciones.

Dumoulin, Michel (2005), Leopold II: Un Roi Génocidaire?. Bruxelles: Académie Royale de Belgique, Classe des Lettres.

Dussel, Enrique (1992), 1492: el encubrimiento del otro: hacia el origen del "mito de la modernidad". Bogotá: Anthropos.

Dussel, Enrique (1995), The Invention of the Americas: Eclipse of "The Other" and the Myth of Modernity. New York: Continuum.

Ela, Jean-Marc (1998), Innovations Sociales et Renaissance de l'Afrique Noire: Les Défis $d u$ 'Monde d'en bas'. Paris: L'Harmattan.

Emerson, Barbara (1979), Leopold II of the Belgians: King of Colonialism. London: Weidenfeld and Nicolson.

Emerton, Patrick (2004), "Paving the Way for Conviction without Evidence - A Disturbing Trend in Australia's Anti-Terrorism Laws”, Queensland University of Technology Law and Justice Journal, 4(92), 1-38.

Epicurus (1926), Epicurus' Morals: Collected and Faithfully Englished. London: Peter Davies.

Escobar, Arturo (1995), Encountering Development: The Making and Unmaking of the Third World. Princeton: Princeton UP.

Eze, Emmanuel Chukwudi (orgs.) (1997), Postcolonial African Philosophy: A Critical Reader. Oxford: Blackwell Publishers.

Fanon, Franz (1963), The Wretched of the Earth. Pref. by Jean-Paul Sartre. New York: Grove Press.

Fanon, Franz (1967), Black Skin, White Masks. New York: Grove Press. 
Fausto-Sterling, Anne (2000), Sexing the Body: Gender Politics and the Construction of Sexuality. New York: Basic Books.

Federici, Silvia (1994), "Journey to the Native Land: Violence and the Concept of the Self in Fanon and Gandhi”, Quest, 8(2), 47-69.

Fisher, William F.; Ponniah, Thomas (2003), Another World is Possible: Popular Alternatives to Globalization at the World Social Forum. London: Zed Books.

Flores, Carlos Crespo (2005), La guerra del agua de Cochabamba: Cinco lecciones para las luchas anti-neoliberales en Bolivia. (http://www.aguabolivia.org, acedido em 2 de Fevereiro de 2005).

Frank, Andre Gunder (1969), Latin America: Underdevelopment or Revolution. New York: Monthly Review.

Freeman, Jody (1997), "Collaborative Governance in the Administrative State”, UCLA Law Review, 45, 1-98.

Furnivall, John Sydenham (1948), Colonial Policy and Practice: a Comparative Study of Burma and Netherlands India. Cambridge: Cambridge UP.

Gandhi, Mahatma (1951), Selected Writings of Mahatma Gandhi. Boston: Beacon.

Gandhi, Mahatma (1956), The Gandhi Reader. Bloomington: Indiana UP.

Gardey, Delphine; Löwy, Ilana (orgs.) (2000), L'invention du naturel. Les sciences et la fabrication du féminin et du masculin. Paris: Éditions des Archives Contemporaines.

Gill, Terry; Sliedgret, Elies van (2005), "A Reflection on the Legal Status and Rights of 'Unlawful Enemy Combatant'”, Utrecht Law Review, 1(1), 28-54.

Glon, Justin C. (2005), "Good Fences Make Good Neighbors: National Security and Terrorism - Time to Fence in Our Southern Border", Indiana International \& Comparative Law Review, 15(2), 349-388.

Graham, Chadwick M. (2005), "Defeating an Invisible Enemy: The Western Superpowers' Efforts to Combat Terrorism by Fighting Illegal Immigration”, Transnational Law E Contemporary Problems, 14(1), 281-310.

Graham, Nora (2005), "Patriot Act II and Denationalization: an Unconstitutional Attempt to Revive Stripping Americans of their Citizenship", Cleveland State Law Review, 52(4), 593-621.

Grosfoguel, Ramon (2000), "Developmentalism, Modernity, and Dependency Theory in Latin America", Nepantla: Views from the South, 1(2), 347-374.

Guha, Ramachandra; Martínez-Allier, Juan (1997), Varieties of Environmentalism: Essays North and South. London: Earthscan.

Guiora, Amos N. (2005), "Legislative and Policy Responses to Terrorism, A Global Perspective”, San Diego International Law Journal, 7(1), 125-172.

Hall, David; Lobina, Emanuele; Motte, Robin de la (2005), "Public Resistance to Privatization in Water and Energy", Development in Practice, 15(3-4), 286-301.

Hall, Stuart (1996), “Who Needs Identity?”, in Stuart Hall; Paul Du Gay (orgs.), Questions of Cultural Identity. London: Sage, 1-17. 
Hansen, Thomas B.; Stepputat, Finn (2004), Sovereign Bodies: Citizens, Migrants, and States in the Postcolonial World. Princeton, New Jersey: Princeton UP.

Haraway, Donna J. (1992), Primate Visions: Gender, Race, and Nature in the World of Modern Science. London: Verso.

Haraway, Donna J. (1997), Modest_Witness@Second_Millenium.FemaleMan@_Meets_ Oncomouse ${ }^{\mathrm{TM}}$ : Feminism and Technoscience. New York: Routledge.

Harding, Sandra (1986), The Science Question in Feminism. Ithaca: Cornell UP.

Harding, Sandra (1998), Is Science Multicultural? Postcolonialisms, Feminisms, and Epistemologies. Bloomington: Indiana UP.

Harding, Sandra (org.) (2003), The Feminist Standpoint Theory Reader: Intellectual and Political Controversies. New York: Routledge.

Harris, George C. (2003), "Terrorism, War and Justice: The Concept of the Unlawful Enemy Combatant", Loyola of Los Angeles International and Comparative Law Review, 26(1), 31-36.

Hasian, Marouf Arif (2002), Colonial Legacies in Postcolonial Contexts. New York: Peter Lang.

Hegel, G. W. F. (1970), Vorlesungen über die Philosophie der Geschichte. Org. E. Moldenhauer e K. M. Michel. Frankfurt am Main: Suhrkamp.

Hobbes, Thomas (1985), Leviathan. London: Penguin Books [1651].

Hochschild, Adam (1999), King Leopold's Ghost: A Story of Greed, Terror, and Heroism in Colonial Africa. Boston: Houghton Mifflin.

Holton, Gerald James (1998), "Einstein and the Cultural Roots of Modern Science”, Daedalus, 127(1), 1-44.

Horkheimer, Max; Adorno, Theodor (1972), Dialectic of Enlightenment. New York: Herder and Herder.

Hountondji, Paulin J. (2002), The Struggle for Meaning: Reflections on Philosophy, Culture, and Democracy in Africa. Athens/Ohio: Ohio University Center for International Studies.

Human Rights Watch (2004), The United States' "Disappeared”. The CIA's Long-Term "Ghost Detainees". New York: Human Rights Watch.

Immigrant Rights Clinic (NYU) (2001), "Indefinite Detention without Probable Cause: A Comment on INS Interim Rule 8 C.F.R. 287.3", New York University Review of Law E Social Change, 26(3), 397-430.

Jaspers, Karl (1952), Reason and Anti-Reason in our Time. New Haven: Yale UP.

Jaspers, Karl (1986), Basic Philosophical Writings. Athens/Ohio: Ohio UP.

Jaspers, Karl (1995), The Great Philosophers. New York: Harcout Brace and Company. Kanstroom, Daniel (2003), "Unlawful Combatants in the United States - Drawing the Fine Line Between Law and War", American Bar Association's Human Right Magazine, Winter 2003. (http://www.abanet.org/irr/hr/winter03/unlawful.html, acedido em 27 de Novembro de 2006). 
Kanstroom, Daniel (2004), "Criminalizing the Undocumented: Ironic Boundaries of the Post-September $11^{\text {th }}$ Pale of Law”, North Carolina Journal of International Law and Commercial Regulation, 29(4), 639-670.

Karp, Ivan; Masolo, Dismas (orgs.) (2000), African Philosophy as Cultural Inquiry. Bloomington: Indiana UP.

Kebede, Messay (2001), "The Rehabilitation of Violence and the Violence of Rehabilitation”, Journal of Black Studies, 31(5), 539-562.

Keller, Evelyn Fox (1985), Reflections on Gender and Science. New Haven: Yale UP.

Klare, Michael (2001), Resource Wars: the New Landscape of Global Conflict. New York: Metropolitan Books.

Koskenniemi, Martti (2002), The Gentle Civilizer of Nations: The Rise and Fall of International Law, 1870-1960. Cambridge: Cambridge UP.

Kreimer, Seth (2003), "Too Close to the Rack and the Screw: Constitutional Constraints on Torture in the War on Terror", University of Pennsylvania Journal of Constitutional Law, 6, 278-374.

Krishnan, Jayanth K. (2004), “India's Patriot Act: POTA and the Impact on Civil Liberties in the World's Largest Democracy”, Law and Inequality: A Journal of Theory and Practice, 22(2), 265-300.

Lansing, J. Stephen (1987), “Balinese 'Water Temples' and the Management of Irrigation”, American Anthropologist, 89(2), 326-341.

Lansing, J. Stephen (1991), Priests and Programmers: Technologies of Power in the Engineered Landscape of Bali. Princeton: Princeton UP.

Lansing, J. Stephen; Kremer, James N. (1993), "Emergent Properties of Balinese Water Temples: Coadaptation on a Rugged Fitness Landscape”, American Anthropologist, 95(1), 97-114.

Lobel, Jules (2002), “The War on Terrorism and Civil Liberties”, University of Pittsburgh Law Review, 63(4), 767-790.

Locke, John (1946), The Second Treatise of Civil Government and A Letter Concerning Toleration. Oxford: B. Blackwell [1690].

Lopes, Paula Duarte (2005), Water with Borders: Social Goods, The Market and Mobilization. Baltimore: The John Hopkins University Press.

Low, Setha (2003), Behind the Gates: Life, Security, and the Pursuit of Happiness in Fortress America. New York: Routledge.

Lucretius (1950), Lucretius on the Nature of Things. New Brunswick: Rutgers UP.

Lugard, Frederick D. (1929), The Dual Mandate in British Tropical Africa. London: W. Blackwood.

Mac Neil, Michael; Sargent, Neil; Swan, Peter (orgs.) (2000), Law, Regulation and Governance. Ontario: Oxford UP.

Malinowski, Bronislaw (1945), "Indirect Rule and its Scientific Planning”, in M. P. M. Kaberry (org.), The Dynamics of Culture Change: An Inquiry into Race Relations in Africa. New Haven: Yale UP, 138-150. 
Mamdani, Mahmood (1996), Citizen and Subject: Contemporary Africa and the Legacy of Late Colonialism. Princeton: Princeton UP.

Mamdani, Mahmood (1999), "Historicizing Power and Responses to Power: Indirect Rule and Its Reform”, Social Research, 66(3), 859-886.

Masolo, Dismas A. (2003), "Philosophy and Indigenous Knowledge: an African Perspective," Africa Today, 50(2), 21-38.

Mbembe, Achille (2001), On the Postcolony. Berkeley: University of California Press.

McCormack, Wayne (2004), "Military Detention and the Judiciary: Al Qaeda, the KKK and Supra-State Law", San Diego International Law Journal, 5, 7-72.

Memmi, Albert (1965), The Colonizer and the Colonized. New York: The Orion Press.

Menefee, Samuel Pyeatt (2004), "The Smuggling of Refugees by Sea: a Modern Day Maritime Slave Trade", Regent Journal of International Law, 2, 1-28.

Mignolo, Walter (1995), The Darker Side of Renaissance: Literacy, Territoriality, \& Colonization. Michingan: University of Michigan Press.

Mignolo, Walter (2000), Local Histories/Global Designs: Coloniality, Subaltern Knowledges and Border Thinking. Princeton: Princeton UP.

Miller, Marc L. (2002), “Immigration Law: Assessing New Immigration Enforcement Strategies and the Criminalization of Migration", Emory Law Journal, 51(3), 963-976.

Minton, Anna (2002), Building Balanced Communities: The US and the UK Compared. London: RICS.

Morris, H. F.; Read, James S. (1972), Indirect Rule and the Search for Justice: Essays in East African Legal History. Oxford: Clarendon Press.

Mörth, Ulrika (org.) (2004), Soft Law in Governance and Regulation. An Interdisciplinary Analysis. Cheltenham, UK: E. Elgar.

Nandy, Ashis (1987), Traditions, Tyranny and Utopias. Essays in the Politics of Awareness. Oxford: Oxford UP.

Nisula, Laura; Sehm-Patomäki, Katarina (orgs.) (2002), We, the Peoples of the World Social Forum. Nottingham: Network Institute for Global Democratization, Discussion Paper 2/2002.

Nkrumah, Kwame (1965), Consciencism; Philosophy and Ideology for Decolonization and Development with Particular Reference to the African Revolution. New York: Monthly Review Press.

Nye, Joseph; Donahue; John (orgs.) (2000), Governance in a Globalizing World. Washington, DC: Brookings Institution.

O’Rourke, Dara (2003), Outsourcing Regulation: Analysing Non-Governmental Systems of Labor Standards Monitoring”, Policy Studies Journal, 31, 1-29.

Olivera, Oscar (2005), Cochabamba! Water War in Bolivia. Cambridge, MA: South End Press.

Oliveira Filho, Abelardo (2002), Brasil: Luta e resistência contra a privatização da água. Report to PSI InterAmerican Water Conference, San José, 8-10 Julho de 2002. (www. psiru.org/Others/BrasilLuta-port.doc, acedido em 23 de Maio 2006). 
Ortega y Gasset, José (1942), Ideas y Creencias. Madrid: Revista de Occidente.

Ortega y Gasset, Jose (2002), What Is Knowledge?. Albany, NY: State University of New York Press.

Osha, Sanya (1999), "Kwasi Wiredu and the Problems of Conceptual Decolonization”, Quest, 13(1/2), 157-164.

Pagden, Anthony (1990), Spanish Imperialism and the Political Imagination. New Haven: Yale UP.

Paracelsus (1967), The Hermetic and Alchemical Writings. New York: University Books Inc.

Paracelsus (1989), Mikrokosmos und Makrokosmos. München: Eugen Diederichs Verlag.

Pascal, Blaise (1966), Pensées. London: Penguin Books.

Passel, Jeffrey S. (2005), Estimates of the Size and Characteristics of the Undocumented Population (US). Washington D.C.: Pew Hispanic Center.

Perham, Margery (1934), “A Re-Statement of Indirect Rule”, Africa: Journal of the International African Institute, 7(3), 321-334.

Polet, François (org.) (2004), Globalizing Resistance: The State of Struggle. London: Pluto Press.

Posner, Richard (2002), “The Best Offense”, New Republic, 2 de Setembro.

Prakash, Gayan (1999), Another Reason: Science and Imagination of Modern India. Princeton: Princeton UP.

Quijano, Anibal (2000), "Colonialidad del poder y classificacion social”, Journal of World-Systems Research, 6(2), 342-386.

Renner, Karl (1965), Die Rechtsinstitute des Privatrechts und ibre soziale Funktion: ein Beitrag zur Kritik des Bürgerlichen Rechts. Sttutgart: Gustav Fischer.

Roach, Kent (2002), "Did September 11 Change Everything? - Struggling to Preserve Canadian Values in the Face of Terrorism”, McGill Law Journal, 47, 893-847.

Rodney, Walter (1972), How Europe Underdeveloped Africa. London: Bogle-L’Ouverture Publications.

Sadat, Leila Nadya (2005), "Ghost Prisoners and Black Sites: Extraordinary Rendition under International Law”, Case Western Reserve Journal of International Law, 37(5-3), 309-342.

Said, Edward (1978), Orientalism. New York: Vintage Books.

Santos, Boaventura de Sousa (1988), Um discurso sobre as ciências. Porto: Afrontamento.

Santos, Boaventura de Sousa (1995), Toward a New Common Sense: Law, Science and Politics in the Paradigmatic Transition. New York: Routledge.

Santos, Boaventura de Sousa (1998), Reinventar a democracia. Lisboa: Gradiva.

Santos, Boaventura de Sousa (2000), A crítica da razão indolente. Contra o desperdício da experiência, para um novo senso comum. Porto: Afrontamento.

Santos, Boaventura de Sousa (2001), "Os processos da globalização”, in B. S. Santos (org.), Globalização: Fatalidade ou utopia?. Porto: Afrontamento, 31-106. 
Santos, Boaventura de Sousa (2002), Toward a New Legal Common Sense. London: Butterworths.

Santos, Boaventura de Sousa (2004), "A Critique of Lazy Reason: Against the Waste of Experience”, in I. Wallerstein (org.), The Modern World-System in the Longue Durée. Boulder: Paradigm Publishers, 157-197.

Santos, Boaventura de Sousa (2005), Fórum Social Mundial: Manual de uso. Porto: Afrontamento.

Santos, Boaventura de Sousa (2006a), "The Heterogeneous State and Legal Pluralism in Mozambique", Law \& Society Review, 40(1), 39-75.

Santos, Boaventura de Sousa (2006b), A gramática do tempo. Porto: Afrontamento.

Santos, Boaventura de Sousa (2006c), The Rise of the Global Left: The World Social Forum and Beyond. London: Zed Books.

Santos, Boaventura de Sousa (org.) (2003a), Conbecimento prudente para uma vida decente: Um discurso sobre as ciências revisitado. Porto: Afrontamento.

Santos, Boaventura de Sousa (org.) (2003b), Democratizar a democracia: os caminhos da democracia participativa. Porto: Afrontamento.

Santos, Boaventura de Sousa (org.) (2003c), Democratizzare la democrazia: I percorsi della democrazia partecipativa. Troina: Cittá Apperta.

Santos, Boaventura de Sousa (org.) (2004a), Semear outras soluções: os caminhos da biodiversidade e dos conhecimentos rivais. Porto: Afrontamento.

Santos, Boaventura de Sousa (org.) (2004b), Democratizar la democracia: Los caminos de la democracia participativa. México: Fondo de Cultura Económica.

Santos, Boaventura de Sousa (org.) (2005a), Democratizing Democracy: Beyond the Liberal Democratic Canon. London: Verso.

Santos, Boaventura de Sousa (org.) (2005b), Produre per vivere: la vie delle produzione non capitalistica. Troina: Cittá Apperta.

Santos, Boaventura de Sousa (org.) (2006), Another Production is Possible: Beyond the Capitalist Canon. London: Verso.

Santos, Boaventura de Sousa (org.) (2007), Another Knowledge is Possible. London: Verso.

Santos, Boaventura de Sousa; García Villegas, Mauricio (2001), El caleidoscopio de las justicias en Colombia. Bogotá: Ediciones Uniandes, Siglo del Hombre.

Santos, Boaventura de Sousa; Meneses, Maria Paula; Nunes, João Arriscado (2004), "Introdução: para ampliar o cânone da ciência: a diversidade epistemológica do mundo", in B. S. Santos (org.), Semear outras soluções. Porto: Afrontamento, 23-101.

Santos, Boaventura de Sousa; Rodríguez-Garavito, César (2005), "Law, Politics, and the Subaltern in Counter-Hegemonic Globalization”, in B. S. Santos; C. Rodríguez-Garavito (orgs.), Law and Globalization from Below: Towards a Cosmopolitan Legality. Cambridge: Cambridge UP, 1-26.

Sassen, Saskia (1999), Guests and Aliens. New York: The New Press. 
Saul, Ben (2005), "Definition of 'Terrorism' in the UN Security Council: 1985-2004”, Chinese Journal of International Law, 4(1), 141-166.

Schiebinger, Londa (1989), The Mind Has No Sex: Women in the Origins of Modern Science. Cambridge, MA: Harvard UP.

Schiebinger, Londa (1999), Has Feminism Changed Science?. Cambridge, MA: Harvard UP.

Sekhon, Vijay (2003), "Civil Rights of Others: Antiterrorism, the Patriot Act, and Arab and South Asian American Rights in Post-9/11 American Society", Texas Forum on Civil Liberties \& Civil Liberties, 8(1), 117-148.

Spivak, G. C. (1999), A Critique of Postcolonial Reason: Toward a History of the Vanishing Present. Cambridge, MA: Harvard UP.

Scheppele, Kim Lane (2004a), “Other People’s Patriot Acts: Europe's Response to September 11”, Loyola Law Review, 50(1), 89-148.

Scheppele, Kim Lane (2004b), "Law in a Time of Emergency: States of Exception and the Temptations of 9/11”, University of Pennsylvania Journal of Constitutional Law, 6(5), 1001-1083.

Scheppele, Kim Lane (2006), "North American Emergencies: The Use of Emergency Powers in Canada and the United States", International Journal of Constitutional Law, 4(2), 213-243.

Schmitt, Carl (2003), The Nomos of the Earth in the International Law of the Jus Publicum Europaeum. New York: Telos Press.

Sen, Jai et al. (orgs.) (2004), World Social Forum: Challenging Empires. New Delhi: Viveka Foundation.

Silverstein, Paul A. (2005), "Immigrant Racialization and the New Savage Slot: Race, Migration, and Immigration in the New Europe", Annual Review of Anthropology, 34, 363-384.

Snyder, Francis (1993), Soft Law and Institutional Practice in the European Community. Florença: European University Institute (IEUI Working Paper LAW, 93/95).

Snyder, Francis (2002), “Governing Globalization”, in Michel Likosky (org.), Transnational Legal Processes: Globalization and Power Disparities. Edinburgh: Butterworths, 65-97.

Soper, Kate (1995), What Is Nature? Culture, Politics and the Non-Human. Cambridge: Cambridge UP.

Steyn, Johan (2004), “Guantanamo Bay: the Legal Black Hole”, International and Comparative Law Quarterly, 53, 1-15.

Strauss, Marcy (2004), “Torture”, New York Law School Law Review, 48, 201-274.

Taylor, Margaret H. (2004), "Dangerous by Decree: Detention without Bond in Immigration Proceedings”, Loyola Law Review, 50(1), 149-172.

Teivainen, Teivo (no prelo), Democracy in Movement: The World Social Forum as a Political Process. London: Routledge. 
Teubner, Gunther (1986), "Transnational Politics: Contention and Institutions in International Politics", Annual Review of Political Science, 4, 1-20.

Toulmin, Stephen (2001), Return to Reason. Cambridge, MA: Harvard UP.

Trawick, Paul B. (2003), The Struggle for Water in Peru: Comedy and Tragedy in the Andean Commons. Stanford: Stanford UP.

Tribunal Internacional de Justiça (2005), "Legal Consequences of the Construction of a Wall in the Occupied Palestinian Territory-Advisory Opinion", Israel Law Review, 38, 17-82.

Trubek, David; Moscher, James (2003), "New Governance, Employment Policy, and the European Social Model”, in Gunther Teubner (org.), Governing Work and Welfare in a New Economy. Berlin: De Gruyter, 33-58.

Trubek, David; Trubek, Louise G. (2005), "Hard and Soft Law in the Construction of Social Europe: the Role of the Open Method of Co-ordination", European Law Journal, 11(3), 343-364.

Tully, James (2007), “The Imperialism of Modern Constitutional Democracy”, in Martin Loughlin; Neil Walker (orgs.), Constituent Power and Constitutional Form. Oxford: Oxford UP.

Tushnet, Mark (1981), The American Law of Slavery, 1810-1860. Princeton: Princeton UP.

Unger, Roberto (1998), Democracy Realized. London: Verso.

Van Bergen, Jennifer; Valentine, Douglas (2006), “The Dangerous World of Indefinite Detentions: Vietnam to Abu Ghraib”, Case Western Reserve Journal of International Law, 37(5-3), 449-508.

Van de Linde, Eric et al. (2002), Quick Scan of Post 9/11 National Counter-terrorism Policymaking and Implementation in Selected European Countries. Leiden: RAND Europe.

Visvanathan, Shiv (1997), A Carnival for Science: Essays on Science, Technology and Development. Oxford: Oxford UP.

Wallerstein, Immanuel M. (1974), The Modern World-system. New York: Academic Press.

Wallerstein, Immanuel M. (2004), World-systems Analysis: An Introduction. Durham: Duke UP.

Williams, Eric (1994), Capitalism and Slavery. Chapel Hill: University of North Carolina Press [1944].

Whitehead, John W.; Aden, Steven H. (2002), "Forfeiting Enduring Freedom for Homeland Security: A Constitutional Analysis of the USA Patriot Act and the Justice Department's Anti-Terrorism Initiatives”, American University Law Review, 51(6), 1081-1133.

Wilson, William Justus (1987), The Truly Disadvantaged: the Inner City, the Underclass and Public Policy. Chicago: University of Chicago Press. 
Wiredu, Kwasi (1990), “Are There Cultural Universals?”, Quest, 4(2), 5-19.

Wiredu, Kwasi (1996), Cultural Universals and Particulars: An African Perspective. Bloomington: Indiana UP.

Wiredu, Kwasi (1997), “African Philosophy and Inter-cultural Dialogue”, Quest, 11 (1/2), 29-41.

Wishnie, Michael J. (2004), "State and Local Police Enforcement of Immigration Laws”, University of Pennsylvania Journal of Constitutional Law, 6(5), 1084-115.

Wrebner, Pnina (1999), "Global Pathways: Working Class Cosmopolitans and the Creation of Transnational Ethnic Worlds”, Social Anthropology, 7(1), 17-37.

Werbner, Richard (2002), "Cosmopolitan Ethnicity, Entrepreneurship and the Nation: Minority Elites in Botswana”, Journal of Southern African Studies, 28(4), 731-53. Zelman, Joshua D. (2002), "Recent Developments in International Law: Anti-Terrorism Legislation - Part One: An Overview”, Journal of Transnational Law E Policy, 11(1), 183-200. 